\title{
INFLUÊNCIA DA FORMA DE ARRAÇOAMENTO DE SUÍNOS EM CRESCIMENTO E ACABAMENTO NA PERFORMANCE E NA QUALIDADE DA CARCAÇA
}

RYMER RAMIZ TULLIO

Orientador: Dr. Abel Lavorenti

Dissertação apresentada à Escola Superior de Agricultura "Luiz de Queiroz", da Universidade de São Paulo, para obtenção do título de Mestre em Nưrição Animal e Pasłagens.

$P|R A C| C A B A$

Estado de São Paulo - Brasil

Abril, 1978 
A memória de minha mãe

HOMENAGEM

Aos meus avós

ROSA

MANOEL

MARIA

MINHA GRATIDÃO

A meu pai

e irmãos

OFERE ÇO

A minha espôsa

FANI SHIRLEI

DEDICO 
Ao Professor Dr. ABEL LAVORENTI, pela segura e valiosa orientação

A EMPRESA BRASILEIRA DE PESQUisa AGROPECUÁRIA , pelos recursos que ofereceu, tornando possível a realização des ta pesquisa.

Aos colegas de pós-graduação CARLOS ROBERTO VIO TO MONTEIRO PACHECO E VALDOMIRO SHIGUERU MYIADA, pela colabora ção na condução do experimento。

Ao Professor Dr。 IRINEU UMBERTo PACKER, pelas sugestões dadas para a análise dos resultados e pela redação do summary.

Aos colegas do Curso de pós-graduação em Nutri ção Animal e Pastagens, pela lealdade e espírito de colaboração. Aos demais Professores e Funcionários do Depar tamento de Zootecnia da ESALQ。 


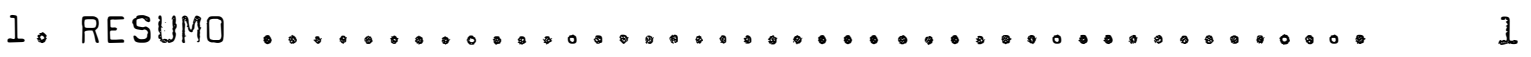

2. INTRODUÇÃO $\ldots \ldots \ldots \ldots \ldots \ldots \ldots \ldots \ldots \ldots \ldots \ldots \ldots \ldots \ldots \ldots \ldots \ldots$

3. REVISÃO DE LiteRATURA $\ldots \ldots \ldots \ldots \ldots \ldots \ldots \ldots \ldots \ldots \ldots \ldots \ldots \ldots \ldots \ldots \ldots \ldots$

3.1. Ração granulada e ração farelada .......... 6

3.1.1.Considerações gerais .............. 6

3.1.2. Effeito da peletização no consumo de ra

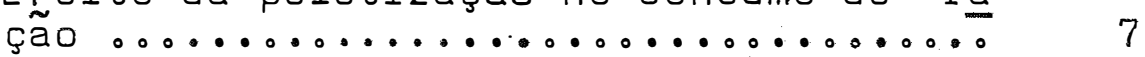

3.1.3. Efeito da peletização no ganho de peso. 9

3.1.4. Efeito da peletização na conversão ali

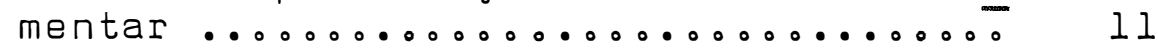

3.1.5. Efeito da peletização na qualidade da carcaça ..................... 13

3.2. Ração formecida à vontade e ração controlada o 14

3.2 .1 Consic rações gerais ............. 14

3.2.2. Efeito do controle alimentar no ganho de peso o...................... 16

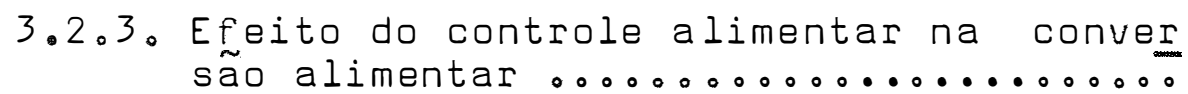

3.2.4. Efeito do controle alimentar na qualida

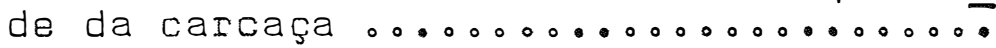

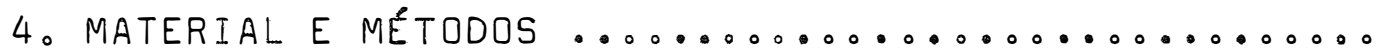

5. RESULTADOS E DISCUSSÃO $\ldots \ldots \ldots \ldots \ldots \ldots \ldots \ldots \ldots \ldots \ldots \ldots \ldots \ldots$

5.1. Consumo de ração .................. 27

5.1.1.Fase de crescimento .............. 27

5.1 .2 . Fase de acabamento ............... 30

5.1 .3 . Período total .................. 32

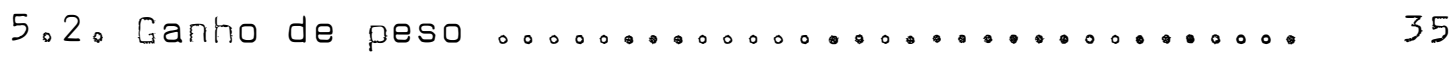

5.2 .1 . Fase de crescimento ............ 35 
5.2.2. Fase de acabamento ................... 40

5.2 .3$. Período total ..................... 42

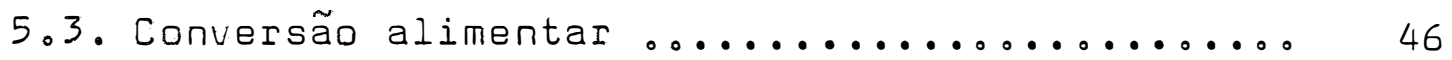

5.3.1. Fase de crescimento ............... 46

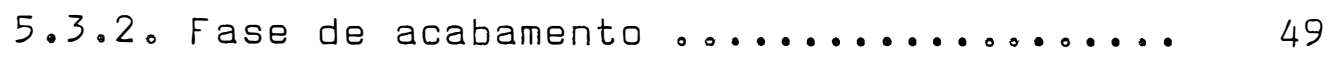

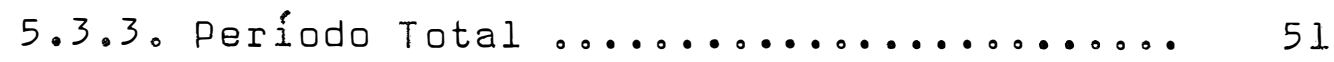

5.4. Qualidade da carcaça .................... 54

5.4.1. Comprimento de carcaça .............. 57

5.4 .2 . Espessura de toicinho ................ 57

5.4 .3 . Area de olho de lombo ............... 59

5.4.4. Peso do pernil .....................6.60

5.4.5.Percentagem de.pernil na carcaça ..... 60

5.4 .6 . Relação carne-gordura ............... 62

5.4 .7 . Rendimento de carcaça .............. 64

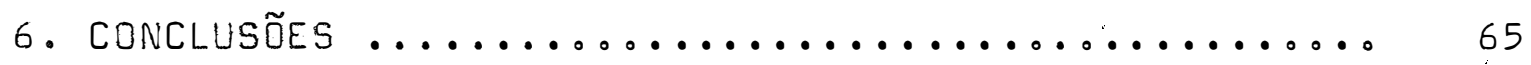

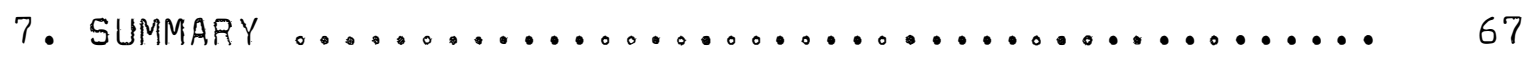

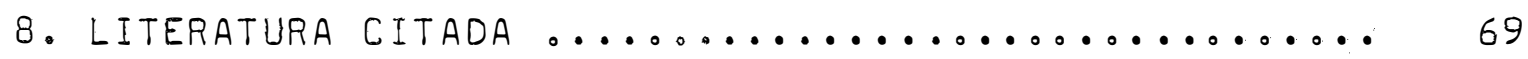

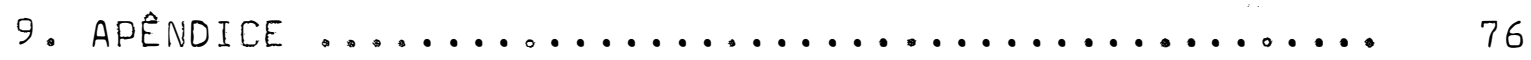




\section{LISTA DE TABELAS}

Página

Tabela 1. Composição Percentual das Rações de Cresci

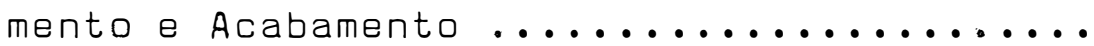

Tabela 2. Consumos Médios Diários de Ração, na Fase

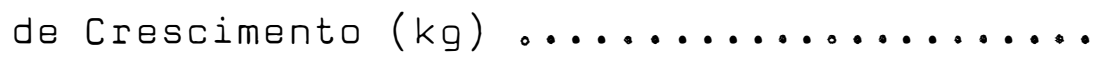

Tabela 3. Análise de Variância do Consumo de Ração na Fase de Crescimento .................

Tabela 4. Consumo Médios Diários de Ração na Fase de Acabamento $(k g) \ldots \ldots \ldots \ldots \ldots \ldots \ldots$

Tabela 5. Análise de Váriância do consumo Alimentar

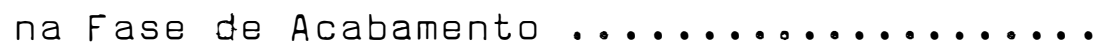

Tabela 6. Consumos Médios Diários de Ração no Pariodo

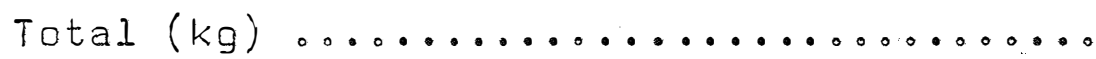

Tabela 7. Análise de Variância do Consumo Alimentar no

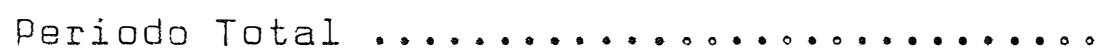

Tabela 8. Anális de Variância, com Desdobramento, do Consumo Alimentar, no Periodo Total .....

Tabela 9。 Ganhos Médios Diários de Paso, na Fase de Crescimento $(k g) \ldots \ldots \ldots \ldots \ldots \ldots$

Tabela 10. Análise de Variância do Ganho de Peso, na

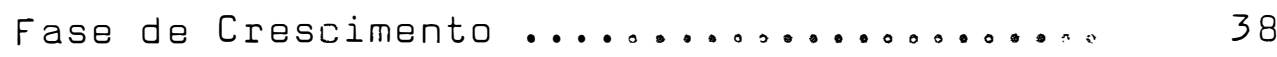

Tabela ll. Ganhos Médios Diários de Peso na Fase de $\underline{A}$ cabamento $(k g) \ldots \ldots \ldots \ldots \ldots \ldots \ldots \ldots \ldots \ldots \ldots \ldots \ldots \ldots \ldots \ldots \ldots$

Tabela 12o Análise de Variância do Ganho de Peso, na Fase de Acabamento,.................... 41

Tabela 13. Ganhos Médios Diários de Peso, no Período

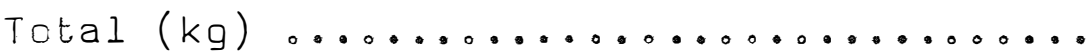


Tabela 14. Análise de Variância do Ganho de Peso, no

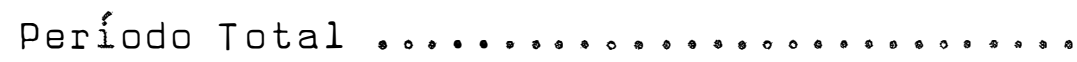

Tabela 15. Análise de Variância, com Desdobramento, do Ganho de Peso, no Perílodo Total ........

Tabela 16. Conversões Alimentares Médias na Fase de Crescimento (kg/kg) ............

Tabela 17. Análise de Variância da Conversão Alimen tar na Fase de Crescimento ...........

Tabela 18. Conversões Alimentares Médias na Fase de A cabamento $(k g / k g) \ldots \ldots \ldots \ldots \ldots \ldots$

Tabela 19. Análise de Variância da Conversão Alimen tar na Fase de Acabamento .............

Tabela 20. Conversões Alimentares Médias, no Período Total $(k g / k g) \ldots \ldots \ldots \ldots \ldots \ldots$

Tabela 2l. Análise de Variância da Conversão Alimen

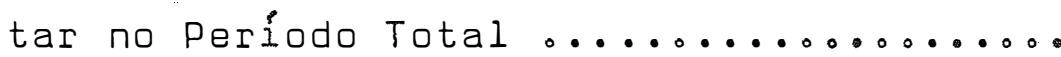

Tabela 22. Médias das Caracteristicas das Carcaças dos

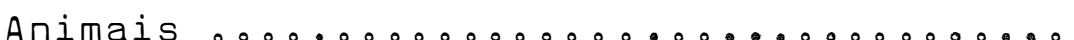

Tabela 23. Análise de Variância das Caracteristicas das Carcaças Ajustadas ............

Tabela 24. Análise de Variância, com Desdobramento, dos Pesos dos Pernis Ajustados ..........

Tabela 25. Análise de Variância, com Desdobramento, das Percentagens de Pernil na carcaça ...

Tabela Al。 Consumo Total de Ração, das Parcelas, no

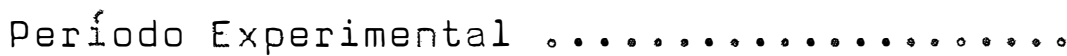

Tabela A2。Consumos Médios Diários de Ração das Repe tições na Fase de Crescimento (kg) ...... 
Tabela A3. Consumos Médios Diários de Ração das Re petições na Fase de Acabamento ( $k g$ ) ...

Tabela A4。 Consumos Médios Diários de Ração das Re petições no Paríodo Total (kg) ........

Tabela A5。 Pesos Médios das Parcelas no Período Ex perimental $(k g) \ldots \ldots \ldots \ldots \ldots \ldots \ldots$

Tabela A6. Pesos Médios e Ganhos Médios de Peso dos Tratamentos no Período Experimental ( $k .9$ )

Tabela A7。 Ganhos Médios Diários de Peso das Repeti ções na Fase de Crescimento (kg) .....

Tabela A8. Ganhos Médios Diários de Peso das Repeti ções na Fase de Acabamento (kg) ........ 84

Tabela A9. Ganhos Médios Diários de Peso das Repeti ções no Período Total ( $k g)$.............

Tabela AlO. Conversões Alimentares Médias das Parce las no Período Experimental o........

Tabela All。Conversões Alimentares Médias Diárias das Repeticões na Fase de Crescimento ( $\mathrm{kg} / \mathrm{kg}$ )

Tabela Al2。 Conversões Alimentares Médias Diárias das Repetições na Fase de Acabamento ( $\mathrm{kg} / \mathrm{kg}$ )

Tabela Al3. Conversões Alimentares Médias Diárias das Repetições no Período Total ( $\mathrm{kg} / \mathrm{kg}$ ) ...

Tabela Al4. Caracteristicas das Carcaças dos Animais do Tratamento Tl ...................

Tabela Al5. Caracteristicas das Carcaças dos Animais do Tratamento $T 2 \ldots \ldots \ldots \ldots \ldots$

Tabela Al6。 Caracteristicas das Carcaças dos Animais do Tratamento T3 .............. 
Tabela Al7. Caracteristicas das Carcaças dos Animais do Tratamento T4 ............. 


\section{LISTA DE FIGURAS}

Página

Figura l. Efeitos dos tratamentos no consumo de ração

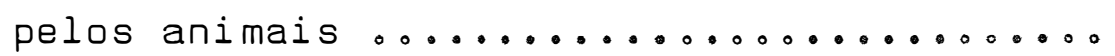

Figura 2. Efeitos dos tratamentos no crescimento dos

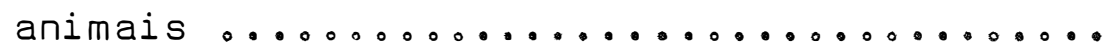

Figura 3. Efeitos dos tratamentos no ganho de pesodos

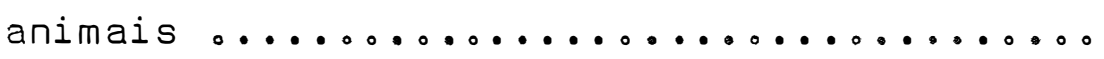

Figura 4. Efeitos dos tratamentos na conversão alimen

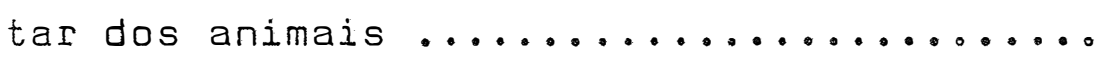


"CURR ICULUM VITAE"

NOME: RYMER RAMIZ TULLIO

DATA DO NASCIMENTO: 06 de janeiro de 1953

LOCAL DO NASCIMENTO: Piracicaba, SP, Brasil

FORMAÇÃo UNIVERSITÁRIA: Engenheiro Agrônomo, 1975, pela Escola Superior de Agricultura "Luiz de Quei roz", Universidade de São Paulo, Pira cicaba, SP。

ATIVIDADE ATUAL: Pesquisador I-101-A da Empresa Brasileira de Pesquisa Agropecuária. 


\section{RESUMO}

0 preseṇte experimento foi realizado para veri ficar a possível influência de formas de arraçoamento na per formance de suínos em crescimento e acabamento e na qualidade da carcaça 。

Foram utilizados 48 suínos da raça Landrace, com peso médio inicial de $24,9 \mathrm{~kg}$ e idade média de 70 dias.

Os animais receberam dieta a base de milho e fa relo de soja, contendo $16 \%$ de proteína bruta na fase de cres cimento ( 24,9 a $61,7 \mathrm{~kg})$ e 14 de proteína bruta na fase de a cabamento $(61,7$ a $95,5 \mathrm{~kg})$ 。

Esses animais foram submetidos aos seguintes tra tamentos:

Tl - Ração farelada, fornecida à vontade (Teste munha) •

T2 - Ração granulada, fornecida à vontade。

T3 - Ração farelada, formecida 2 vezes ao dia em quantidades controladas。

T4 - Ração granulada, formecida 2 vezes ao dia em quantidades controladas。

Os animais foram mantidos em baias com piso con 
cretado, lavadas diariamente, e receberam água à vontade. Cada unidade experimental foi composta por 3 animais, 2 machos cas trados e 1 fêmea.

O delineamento experimental utilizado foi o de blocos ao acaso, usando um esquema fatorial $2 \times 2$ ( 2 tipos de ração e 2 tipos de formecimento) para a performance de cresci mento e um esquema fatorial $2 \times 2 \times 2$ ( 2 tipos de ração, 2 ti pos de formecimento e 2 sexos) para a qualidade da carcaça。

Ao fim do perído experimental ( 108 dias) os a nimais dos tratamentos Tl, T2, T3 e T4 apresentaram, respecti vamente, consumos médios de ração de 2,$63 ; 2,32 ; 2,23$ e $2,20 \mathrm{~kg}$, ganhos médios diários de peso de 0,772;0,703; 0,718 e 0,722 kg e conversões alimentares médias de 3,42; 3,28; 3,09 e 3,05。

A análise estatística mostrou que os animais que receberam o tratamento Tl tiveram ganhos médios diários, esta tisticamente $(P L 0,05)$, maiores do que aqueles dos outros tra tamentos. Para a conversão alimentar, os suínos que receberam a dieta granulada apresentaram, estatisticamente $(P L 0,05)$, me lhores conversões do que aqueles alimentados com a ração fare lada. Quanto ao tipo de formecimento, os animais que tiveram ração controlada apresentaram conversões alimentares significa tivamente $(P L 0,01)$ melhores do que os suínos recebendo ração à vontade. Nesse aspecto ainda, os animais dos tratamentos T3 e T4 foram os que apresentaram melhores conversões alimentares médias.

0 comprimento de carcaça somente foi estatisti camente diferente $(P L O, 01)$, quando os sexos foram analisados, sendo que as fêmeas apresentaram maior comprimento de carcaça.

Para espessura de toicinho, o tipo de ração gra nulada foi superior $(P L 0,05)$ ao tipo farelada, isto é, os ani mais que foram alimentados com rações granuladas apresentaram menor espessura de toicinho. Com o formecimento controlado de 
ração, os suinos tiveram, significativamente $(P L 0,05)$, menor espessura de toicinho.

O tratamento, que permitiu aos animais obterem maior $(P L 0,01)$ peso de pernil, foi o Tl。

A área de olho de lombo, a relação carne-gordü ra e o rendimento de carcaça, não apresentaram diferenças sig̣ nificativas, devido aos tratamentos utilizados. 
Em uma criação de suínos, o custo total de pro dução é resultante dá somatória de uma série de fatores e en tre eles, sem dúvida, o mais importante vem a ser o referen te à alimentação. Esse fator, segundo POND e MANER (1974), re presenta 55 a $85 \%$ dc custo total de produção, dependendo frín cipalmente do custo dos alimentos. Por essa razão, é altamen te importante que dietas econômicas, bem como nutricionalmente balanceadas, sejam fornecidas durante todas as fases do ci clo vital dos suínos.

Com base nessa afirmativa, quolquer manejo na alimentaçồ que resulte em um melhor aproveitamento da ração pelos suínos, deve ser utilizado, pois resultará em um menor custo de produção.

As rações balanceadas podem ser fornecidas aos animais nas formas farelada ou granulada, sendo que há dois tipos de formecimento:

a) ração controlada - quando Ĺme certa quantidade de ração é fornecida diariamente;

b) ração à vontade ou ad libitum - quarido o a nimal tem livre acesso ao alimento que está permanentemente a sua disposição. 
A ração na forma farelada vem a ser a mistura de alimentos energéticos e protéicos, fontes de minerais e vi taminas, aditivos, preparada em misturadores horizontais ou verticais sem qualquer tratamento posterior.

A ração granulada ou peletizada vem a ser a mistura farelada que é comprimida através de orifícios de um disco, tomando a forma de grânulos. Esse processo é efetuado através de aquecimento e adição de produtos aglutinantes tais como melaço; gordura, bentonita ou ainda farinha de guar, que são necessários para assegurar ao grânulo uma textura e firme za características. 0 processo de aquecimento sob pressão po de prejudicar a qualidade da ração devido ao desdobramento de proteínas e vitaminas pela ação do calor em excesso. Há ne cessidade de que as condições de peletização sejam muito bem controladas.

Diversos autores apresentam vantagens da ração peletizada sobre a farelada, indicando uma melhor conversão a limentar, embora, por outro lado, a peletização aumente o cus to de produção industrial da ração.

0 manejo moderno de alimentação recomenda ra ção controlada para algumas categorias de suínos, como porcas gestantes e cachaços, enquanto outras categorias devem rece ber ração à vontade, como é o caso de porcas lactantes. No ca so dos animais em crescimento e acabamento, existem pesquisa dores que recomendam o fornecimento de ração controlada que resultaria em melhor afroveitamento do alimento e melhor qua lidade de carcaça, enquanto outros autores preconizam o forne cimento de ração à vontade, para obter melhores ganhos diá rios e melhor conversão alimentar.

Como em nosso meio ainda são poucos os traba lhos de pesquisa relacionados com formas de fornecimento de ração e manejo de alimentação de suínos, o presente experimen to foi realizado para verificar a possível influência das vá rias formas de arraçoamento na performance de suínos em cres cimento e acabamento e na qualidade da carcaça. 


\section{REVISÃO DA LITERATURA}

\subsection{Racăo granulada e Racão farelada}

\subsubsection{Considerações Gerais}

Os diferentes métodos de processamento podem a fatar a aceitabilidade e utilização de alimentos pelos suí nos. De particular interesse é a peletização da ração. Nos EUA, tem ocorrido um aumento no percentual de concentrados protéicos e rações para suínos, comercializados na forma gra nulada. Os resultados de experimentos recentes indicam que a peletização parece ser conveniente, especialmente quando são consideradas rações para suínos em crescimento e acabamento (JENSEN, 1966)。

A influência da peletização de rações farela das vem sendo estudada, por mais de 20 anos, por diversos pes quisadores.

Para NICHOLSON (1976) a ração granulada apre senta as seguintes vantagens em sua utilização: são mais fá ceis de manipular a granel; em comedouros automáticos fluem mais rapidamente, pois enquanto que para a ração farelada a declividade do comedouro deve ser de $60^{\circ}$, para a granulada po 
de ser de $45^{\circ}$; as perdas de alimento são reduzidas, possivel mente, resultando em melhor conversão alimentar e menor produ ção de poeira. A área de armazenamento é também menor, devido ao aumento da densidade da ração que passa de 1,9 a $2,2 \mathrm{~m}^{3} /$ ton na forma farelada a $1,65 \mathrm{~m}^{3} /$ ton na forma granulada. Quando as rações são produzidas na granja, o alto custo inicial do e quipamento para peletização é apontado como a principal des vantagem.

Além das vantagens citadas anteriormente, WAR DEN (1971) relaciona outras como a possível destruição de ini bidores de crescimento ou a liberação de enzimas benéficas, o aumento da palatabilidade do pélete, graças ao uso de gordura ou melaço como aglutinantes e a possível destruição de bacté rias, principalmente Ślmonella.

Em um artigo publicado em 1975, BRoOks relata que a peletização aumenta o custo da dieta, mas, que essa des pesa adicional é recuperada pela melhor conversão alimentar obtida. Acrescenta ainda, que esse melhor aproveitamento do a limento pode ser devido a dois fatores: o primeiro, é que o processo de peletização envolvendo a aplicação de calor e pres são, aumenta a digestibilidade dos nutrientes da dieta; o se gundo é a redução das perdas com uma menor produção de poe ra。

\subsubsection{Efeito da peletização no consumo de ração}

A esse respeito, a literatura é um tanto con trovertida, isso porque, há trabalhos que apresentam um consu mo maior para as dietas granuladas (SEERLEY et alii, 1962a ; JENSEN, 1966 e HINTZ e GARRETT, 1967) e outros, uma maior in gestão de alimentos quando as rações foram fareladas (JENSEN e BECKER, 1965; JENSEN, 1966; CHAMBERLAIN et alii, 1967; BAIRD e McCULLOUGH, 1971 e YeN et alii, 1971). A maioria dos traba lhos não levou em conta o consumo de alimento sendo que os au 
tores preferem manipular os dados referentes a ganho de peso e conversão alimentar. Portanto, são em número reduzido as pu. blicações que consideram o efeito da peletização sobre o con sumo diário de alimento.

Um sumário de 30 ensaios realizados em 7 esta ções experimentais americanas, entre os anos de 1953 e 1964 , foi apresentado por JENSEN em 1966 e mostrou um consumo médio $1,2 \%$ maior para a ração granulada $(2,58$ e $2,61 \mathrm{~kg} / \mathrm{dia}$ para ra ção farelada e granulada, respectivamente). Nessa mesma publi cação, foi apresentado o resumo dos resultados dos ensaios da Universidade de Illinois e esse dava uma vantagem para a dieta farelada de $9,4 \%$ na fase de crescimento e 3,3\% na fase de acabamento, no referente ao consumo de alimento, em compa ração com rações granuiladas.

Os resultados obtidos na Universidade de II linois, estão de acordo com aqueles encontrados por BAIRD e MCCULLOUGH (1971).

De acordo com os estudos de YEN et alii (1971), não houve diferença estatisticamente significativa entre os consumos de rações fareladas e granuladas. No entanto, o con sumo de ração farelada foi, em média, $7,4 \%$ maior do que o con sumo da granulada. Esse resultado concorda com os encontrados POI LARSEN e OLDFIEL $?$ em 1960 e BAIRD em 1973.

Entretanto, os resultados obtidos por CHAMBER LAIN et alii (1967), mostraram um maior consumo de ração fare lada do que granulada $(2,85 \times 2,57 \mathrm{~kg} / \mathrm{dia})$. Essa diferença foi estatisticamente significativa. Os autores acrescentaram ainda que com rações granuladas a incidência de úlceras esofa gogástricas nos suínos foi maior.

SEERLEY et alii (1962a) observaram que o consu mo de ração granulada foi de $3,39 \mathrm{~kg} / \mathrm{dia}$ e o consumo da ração farelada foi de $3,26 \mathrm{~kg} / \mathrm{dia}$ ou seja, o consumo foi $4 \%$ main pa ra a ração granulada. Também nesse ensaio a diferença não foi 
estatisticamente significativa.

Alguns autores encontraram consumo alimentar estatisticamente maior para a ração granulada, como por exem plo HINTZ e GARRETT (1967), que obtiveram consumos diários de 2,98 e $2,77 \mathrm{~kg}$ para as formas granulada e farelada, respecti vamente.

o consumo de alimento pelos leitões geralmente é maior, quando as rações são apresentadas na forma farelada. Essa afirmativa é baseada nos ensaios efetuados por JENSEN e BECKER em 1965. Em 4 experimentos, esses pesquisadores obti veram sempre maior consumo diário com rações fareladas.

\subsubsection{Efeito da peletização no ganho de peso}

Com relação aos efeitos da peletização sobre o ganho de peso, vários experimentos foram realizados. A varia ção nos resultados é muito grande, apesar da maior parte de les serem favoráveis à ração na forma granulada.

Testes conduzidos na Universidade de Illinois, indicaram que o ganho de peso não foi afetado pela forma da ração, quando se consideraram os animais na fase de crescimen to, mas na fase de acabamento, o ganho de peso foi aumentado em $6,4 \%(0,84$ e $0,90 \mathrm{~kg} / \mathrm{dia})$ para a ração na forma granulada (PERRY, 1972).

CHAMBERLAIN et alii. (1967) testaram o efeito das formas de ração sobre a performance dos suínos e encontraram um ganho de peso diário dos animais recebendo ração na forma granulada, estatisticamente maior $(P<0,05)$ do que aqueles que receberama alimentação na forma farelada. Esses resultados foram semelhantes aos encontrados por BAIRD e MCCLLLOUGH (1971), os quais, mostraram que a pele tização da ração aumentou o ganho de peso em $7,9 \%$. 
Com a peletização das rações, diversos autores verificaram maiores ganhos de peso, sendo que os percentuais de aumento foram de $14,4 \%$ (CONRAD e BEESON, 1958), $11,5 \%$ (SEE ERLEY et alii, 1962a), 7,2\% (GILL e OLDFIELD, 1965), 2,3\% (SMIDT et alii, 1965), 4,9\% (BRAUDE e ROWELL, 1966),6,2\% (JEN SEN, 1966), 6,5\% (HINTZ e GARRETT, 1967), 6,0\% (HANKE et alii, 1972 ) e 4,9\% (BAIRD, 1973), quando comparados aos ganhos de pe so obtidos com rações na forma farelada.

Alguns pesquisadores, porém, não encontraram diferenças estatísticas no ganho de peso de suínos quando a forma da ração (farelada e granulada) foi testada (TRIBbLE et alii, 1973).

Um trabalho importante a esse respeito, é o do NCR-42 COMMITTEE ON SWINE NUTRITION (1969), onde os resulta dos de 10 estações experimentais foram analisados e apresenta ram um ganho médio diário de peso de 0,77 kg para a ração na forma farelada e $0,78 \mathrm{~kg}$ para a forma granulada.

Segundo DANIELSON (1976), apesar dos ganhos de peso não diferirem estatisticamente, os animais que receberam a ração na forma granulada apresentaram uma tendência em au mentar a média diária de ganho de peso.

Por outro lado, LARSEN e OLDFIELD (1960) conse guiram um ganho diário de peso maior ( $12,4 \%$ para os suínos que receberam a ração farelada $(0,82 \mathrm{~kg})$ do que para os ani mais alimentados com ração granulada $(0,73 \mathrm{~kg})$.

Da mesma forma, YEN et alii (1971) utilizando uma ração à base de milho e farelo de soja observaram que o ganho de peso foi ligeiramente superior (3,4\%) para os anima is que receberam a ração na forma farelada, mas à medida que se introduziu glúten de milho na dieta, os ganhos de peso fo ram melhores para os suínos alimentados com ração na forma granulada.

Para leitões, a forma da ração não influenciou 
significativamente o gantio de peso, apesar de haver uma peque na tendência de aumentar o ganho, com o fornecimento de rações na forma farelada (JENSEN e BECKER, 1965).

3.1.4. Efeito da peletização na conversão alimentar

A maioria das pesquisas realizadas para testar - efeito da peletização mostrou que a conversão alimentar de suínos que receberam rações na forma granulada, foi melhor ou igual à conversão dos animais alimentados com rações na forma farelada.

SEERLEY et alii (1962a), SMIDT et alii (1965), BRAUDE e ROWELL (1966), CHAMBERLAIN et alii (1967), NCR-42 COMMITTEE ON SWINE NUTRITION (1969), BAIRD e MCCULLOUGH(1971), HANKE et alii. (1972), PERRY (1972), BAIRD (1973) e TRIBBLE et alii. (1973), encontraram conversão alimentar estatisticamente melhor para os suínos que receberam as rações na forma granu lada.

Para outros pesquisadores, a conversão alimen tar apresentada pelos animais que receberam ração na forma granulada, apesar de não diferir estatisticamente daquela dos que eram alimentados com ração na forma farelada, mostrou uma tendência em sei melhor (CONRAD e BEESON, 1958; ENGLAND et alii, 1965; GILL e OLDFIELD, 1965; HINTZ e GARRETT, 1967 , YEN et alii, 1971 e DANIELSON, 1976)。

JENSEN (1966) mostrou em sua publicação que a vantagem da ração na forma granulada sobre a forma farelada foi variável entre 5 e $13 \%$, no referente à conversão alimen tar。

$U_{m}$ ensaio em que a conversão alimentar foi sig nificativamente melhor para a forma farelada, foi o de auto ria de LARSEN e OLDFIELD (1960), onde a conversão alimentar para os animais recebendo a ração granulada era de 3,71: 1 
e a conversão para os suínos alimentados com a ração na forma farelada era 3,37 : 1 . Os autores não encontraram uma razão para explicar a pobre performance dos suínos alimentados com rações granuladas. As razões encontradas pelos pesquisadores para explicar essas variações nos resultados, tanto para con sumo de alimento e ganho de peso como para conversão alimen tar, são bastante variáveis.

- processo de peletização parece modificar qui mica ou fisicamente certos constituintes da ração. Isso pode ser explicado pelo fato de que quando os péletes, quer como simples ingrediente ou como ração completa, são moídos e for necidos na forma farelada, o efeito benéfico da peletização permanece (JENSEN e BECKER, 1965)。

o conteúdo de matéria seca dos péletes é geral mente ao redor de $1 \%$ maior do que a da ração na forma farela da (JENSEN e BECKER, 1965 e BAIRD, 1973). No entanto, os re sultados obtidos por LARSEN e OLDFIELD (1960) estão em desa cordo com essa afirmativa, pois não observaram diferenças na matéria seca das rações farelada ou granulada.

Em testes efetuados por BAIRD (1973), o conteú do de fibra bruta da ração não variou com a utilização do pro cesso de peletização. Em contraste, para LARSEN e OLDFIELD (1960) e JENSEN e BECKER (1965), o processo de peletização re duziu o conteúdo de fibra da ração

0 cozimento e a gelatinização parcial do amido pode ocorrer durante o processo de peletização (JENSEN,1966)。 Essa afirmativa é apoiada por JENSEN e BECKER (1965) e BAIRD (1973), os quais observaram que o processo de peletização, tor nou a fração carboidráto mais susceptível à ação enzimática.

A digestibilidade da matéria seca apesar de não ser significativamente diferente, mostrou uma tendência em ser maior para as rações na forma farelada (SEERLEy et 
alii, 1962a e BAIRD, 1973). A razão encontrada por SEERLEy et alii (1962a) para explicar esse aumento da digestibilidade é que ocorre um decréscimo na matéria seca fecal quando a ração é fornecida na forma farelada. A ingestão de matéria seca diá ria pelos suínos, segundo observações de BAIRD (1973), foi se melhante para as duas formas de ração.

Outro ponto a ser considerado é o referente a absorção e retenção de nitrogênio. A quantidade de nitrogênio total na dieta foi maior ( $P(0,05)$ para as rações na forma granulada (JENSEN e BECKER, 1965). Para YEN et alii. (1971), quando os animais ingeriram iguais quantidades de nitrogênio, a absorção e retenção desse elemento foi significativamente ( $P$ L 0,05) maior para as rações na forma granulada.

No referente à energia, segundo BAIRD (1973), tanto as energias bruta e digestível, como a energia metaboli zável, foram maiores para a ração na forma farelada ( 3769 vs $3654 \mathrm{Kcal} / \mathrm{kg} ; 3419$ vs $3254 \mathrm{Kcal} / \mathrm{kg}$ e 3265 vs $3098 \mathrm{Kcal} / \mathrm{kg}$, respectivamente) quando comparadas com dietas granuladas. En tretanto, LAWRENCE (1971) encontrou valores de energia diges tível e metabolizável da ordem de 2952 e 2749 Kcal/kg para a ração farelada e 3122 e $2905 \mathrm{Kcal} / \mathrm{kg}$ para a ração granulada, respectivamente.

\subsubsection{Efeito da peletização na qualidade da carcaça}

Os trabalhos que levam em conta a influência da forma da ração sobre a qualidade da carcaça são em número re duzido. Isso é devido, principalmente, ao fato de que é neces sário abater o animal para poder avaliar adequadamente os ca racterísticos da carcaça.

De maneira geral, os característicos usados pa ra estimar a qualidade da carcaça não são muito variáveis.Des sa forma, vários autores (BRAUDE e ROWELL, 1966; HINTZ e GA- 
RETT, 1967; BAIRD E MCCULLOUGH, 1971; BAIRD, 1973 e. DANIEL SON, 1976) quando mediram o comprimento de carcaça não encon traram diferenças estatísticas significativas.

No referente a espessura de toicinho, existe controvérsia, pois há autores como BRAUDE e ROWELL (1966), HINTZ e GARRETT (1967) e BAIRD (1973) que encontraram toici nho de menor espessura quando a ração fazelada foi formecida aos animais。 Já DANIELSON (1976) não encontrou diferenças na espessura de toicinho, devido a forma da ração. Em contrapar tida, BAIRD e MCCuLLOUGH (1971), reportaram uma tendência de menor espessura de toicinho para a ração na forma granulada, sem, contudo, ser estatisticamente diferente.

$$
\text { BAIRD e. MCCULLOUGH (1971), BAIRD (1973) e DANI }
$$
ELSON (1976) não encontraram variação significativa na área de olho de lombo. No entanto, BRAUDE e ROWELL (1966) obtive ram áreas de olho de lombo estatisticamente maiores em suínos que receberam a ração na forma granulada.

A percentagem de pernil na sarcaça não dife riu significativamente entre as duas formas de ração (BAIRD, 1973). Da mesma forma, não houve diferenças significativas no peso de permil (DANIELSON, 1976).

3.2. Ração fornecida à vontade e Ração controlada

3.2 .1 . Considerações gerais

o princípio básico do controle alimentar é fa zer com que os animais consumam somente o alimento necessário para o seu desenvolvimento normal. Dessa forma, para contro lar a ingestão, poderíamos utilizar um dos seguintes sistemas:

a) fornecer uma certa quantidade de ração por dia, baseada no peso vivo do animal; 
b) intercalar períodos em que o animal tem li vre acesso à ração, com períodos em que o animal é mantido em je jum;

c) dar ração alta em fibra, à vontade, em come douros automáticos. Nesse caso, a fibra irá diluir a ração e limitar a ingestão de nutrientes;

d) dividir a ração diária em várias refeições, por exemplo, em $2,3,4,5,8$ ou 12 pequenas porções.

BABATUNDE et alii (1966) e FRIEND e CUNNINGHAM (1967), estabeleceram que a restrição alimentar, quando impos ta em um estágio adequado de crescímento do suíno, resulta em aumento na proporção de cortes cárneos em relação à gordura.

Uma redução na frequência de alimentação em ra tos de laboratório, induziu a mudanças marcantes no metabolis mo intermediário, isso, porque ocorreu um aumento da taxa de lipogênese e um aumento nos depósitos de gordura no corpo (SHARMA et alii, 1973).

Ds valores de energia digestivel e metabolizável da dieta não foram afetados pela frequência de alimenta ção, mas a lipogênese foi aumentada, devido a um acréscimo no nível de energia consumida (SHARMA et alii, 1973).

A restrição na ingestão de alimento de suínos, recebendo rações com altos níveis protéicos, resultou em uma maior $(P<0,05)$ concentração de ácido linoleico do que aque la presente em animais que receberam a mesma ração, à vontade. Dessa forma, houve uma tendência em produzir uma gordura mais insaturada. Essa diferença pode ser atribuida à reduzida ta xa de ganho de peso (STAHLY e WAHLSTROM, 1973). BABATUNDE et alii. (1966) mostraram que o ganho médio diário de peso esta va relacionado positivamente com os ácidos graxos saturados e negativamente com os ácidos graxos insaturados. 
3.2.2. Efeito do controle alimentar no ganho de peso

A esse respeito, a quase totalidade dos autores encontrou um ganho de peso superior para os suínos que re ceberam ração à vontade, quando comparados com aqueles aos quais foi aplicada a restrição no consumo e maior frequência de alimentação.

CRAMPTON et alii (1954) quando testaram o efei to das estações do ano e da restrição da alimentação, encon traram um maior ganho de peso, tanto no inverno como no verão, para os animais que receberam ração à vontade. o ganho de peso foi $35 \%$ maior no inverno e $16 \%$ maior no verão para os ani mais alimentados à vontade.

À medida que se acentua a restrição na inges tão de alimento, há uma tendência em reduzir o ganho de peso. Essa afirmativa está baseada no trabalho de BRAUDE et alii (1958) que usaram várias tabelas de consumo com diferentes graus de restrição alimentar. Esses resultados concordam com aqueles obtidos por SMOLINSKI et alii (1963) e MEADE et alii $(1964)$.

Apesar da diferença não ter sido tão acentuada (em torno de 7\%) PICKETT et alii. (1963) e SMIDT et alii (1965) também encontraram um ganho de peso maior para os animais que receberam a ração à vontade.

Da mesma forma, BECKER et alii. (1964), BABATUN DE et alii. (1966) e KLAY et alii (1969) em seus respectivos trabalhos, reportaram diferenças significativas entre os ga nhos de peso dos suínos que receberam rações à vontade e con trolada. Essas diferenças foram favoráveis ao fornecimento à vontade.

Segundo STAHLY e WAHLSTROM (1973), o ganho de peso para animais na fase de acabamento, não diferiu, estatis 
ticamente, quando comparou os suínos recebendo ração controla da e ração à vontade. No entanto, pareceu haver uma tendência do ganhe de peso ser maior, quando a ração foi fornecida à vontade.

Quando o formecimento à vontade e a frequência de alimentação ( 1,2 ou 4 refeições diárias) foram compara dos, no referente a ganho de peso, a ração fornecida à vonta de foi estatisticamente $(P \angle 0,05)$ maior do que os forneci mentos de 1,2 ou 4 refeiçães por dia (PICKETT et alii, , 1964). CROMWELL et alii (1965) em experimento semelhante, com pararam o gamho de peso de suínos alimentados à vontade e re cebendo $1,2,8$ ou 12 refeições diariamente e verificaram que a ração fornecida 2 vezes ao dia foi semelhante à forneci da à vontade. Entretanto, com o fornecimento de 1,8 ou 12 porções diárias, os resultados de ganho de peso encontrados, foram significativamente menores quando comparados com a ra ção à vontade.

WALKER (1970) não encontrou diferenças no ga nho de peso, entre os fornecimentos de 2,4 e 8 refeições por dia, apesar de haver uma tendência em aumentar o ganho, quan do foi reduzido o número de refeições diárias.

Comparando a frequência de alimentação de 1 e 5 vezes, diariamente, BRAUDE et alii. (1963) e FRIEND e CUNNIN G.4AM (1964, 1965 e 1967), reportaram ganhos semelhantes para os dois tipos de fornecimento de ração.

3.2.3. Efeito do controle alimentar na conversão ali mentar

Há discordância entre os autores quanto aos e feitos que o controle no fornecimento de ração possa exercer sobre a conversão alimentar. Pesquisadores como BECKER et alii (1964) e BABATUNDE et alii. (1966) quando limitaram a in 
gestão de alimento pelos suínos, encontraram uma melhor con versão para os animais que receberam ração à vontade. Entretanto, CRAMPTON et alii (1954), BECKER et alii (1963), PICKETT et alii (1963), SMOLINSKY et alii (1963) e STAHLY e WAHLSTROM (1973) também restringiram a alimentação e verificaram que a conversão alimentar não foi afetada, isto é, foi semelhante en tre os animais que receberam ração à vontade e os que tiveram controle no consumo.

Essa variação nos resultados pode ocorrer numa mesma publicação, como é o caso de KLAY et alii (1969), onde em 3 experimentos, os resultados de 1 deles, foram favoráveis à restrição alimentar e os resultados dos outros 2 ensaios mostraram vantagens para a alimentação à vontade, quando a conversão alimentar dós suínos foi considerada.

SEERLEY et alii (1962a), MEADE et alii (1964) e SMIDT et alii (1965), quando compararam fornecimento à von tade e restrição no consumo, verificaram que os animais aos quais se empregou o controle da alimentação, apresentaram con versões alimentares, estatisticamente melhores, do que aqué les com livre acesso à alimentação.

Alguns autores constataram uma tendência de me Lhorar a conversão alimentar, à medida que a restrição no for necimento de ração foi aumentada (BRAUDE et alii, 1958, SMO LINSKY et alii, 1963 e MEADE et alii, 1964)..

PICKETT et alii (1964) e CROMWELL et alii(1965) estudaram o fornecimento à vontade e em 1,2 e 4 vezes por dia e 1, 2, 8 e 12 vezes diariamente, respectivamente. Os estudos dos primeiros autores mostraram que a conversão alimentar foi significativamente melhor para os suínos que receberam ra ção à vontade ou em 2 refeições diárias, enquanto os resultá dos dos outros autores indicaram que a conversão alimentar dos animais alimentados à vontade foi significativamente $(P \angle 0,05)$ melhor que daqueles alimentados 1 , 8 ou 12 vezes diariamente. 
Segundo WALKER (1970), não houve diferenças en tre as conversões alimentares de animais que recebiam 2,4 ou 8 rafeições diárias, entretanto, foi notada uma tendência de melhorar a conversão, à medida que reduzia a frequência de a limentação.

A comparação da conversão alimentar entre suí nos recebendo uma ou cinco refeições diárias, não apresentou diferenças estatísticas (BRAUDE et alii, 1963 e FRIEND e CUNNINGHAM, 1965 e 1967). Em ensaio anterior, FRIEND e CUNNIN GHAM (1964), fizeram a mesma comparação em dois experimentos: no primeiro, os resultados foram semelhantes para conversãa a limentar, mas no segundo, os animais que receberam apenas uma refeição por dia obtiveram melhor conversão $(P L 0,01)$ que a queles alimentados cinco vezes diariamente.

\subsubsection{Efeito do controle alimentar na qualidade da carcaça}

o comprimento de carcaça é um parâmetro que pou co varia, sob a ação de fatores de nutrição ou alimentação. BRAUDE et alii. (1958), STOTHERS (1963), BABATUNDE et alii (1966), KLAY et alii. (1969) e STAHLY e WAHLSTROM (1973) não en contraram diferenças no comprimento das carcaças quando compa raram a alimentação à vontade com o fornecimento controlado.

$$
\text { Da mesma forma, a variação na frequência de }
$$

fornecimento de alimento não afetou, de modo significativo, o comprimento de carcaça (BRAUDE et alii, 1963; FRIEND e CUNNIN GHAM, 1964 e 1967; PICKETT et alii, 1964; CROMWELL et alii. 1965 e WALKER, 1970).

Estudando a espessura de toicinho de animais a limentados à vontade ou com restrição alimentar, SMOLINSKY et alii (1963) e STOTHERS (1963) não observaram diferença signi ficativa, enquanto MEADE et alii. (1964), BABATUNDE et alii 
(1966), KLAY et alii. (1969) e STAHLY e WAHLSTRON (1973) verifi caram que a espessura de toicinho foi significativamente menor para os suínos que receberam ração controlada.

Alguns pesquisadores testaram o formecimento da ração à vontade e em 1, 2 e 4 (PICKETT et alii, 1964), 1, 2, 8 e 12 (CROMWELL et alii, 1965) ou 2, 4 e 8 (WALKER, 1970) refei ções diárias. A análise dos resultados, não indicou diferen ças significativas na espessura de toicinho.

No referente à área de olho de lombo MEADE et alii. (1964), verificaram que à medida que restringiram a ali mentação, embora não houvesse diferenças estatisticamente sig nificativas, houve uma tendência em aumentar a área de olho de lombo. SMOLINSKY et alii. (1963), STOTHERS (1963), KLAY et alii (1969) e STAHLY e WAHLSTROM (1973) também não encontraram va riação significativa quando controlaram o fornecimento de ra ção. No entanto, BABATUNDE et alii. (1966) verificaram que os lombos dos animais que receberam ração controlada apresenta ram área, estatisticamente $(P<0,05)$, maior que a daqueles que tiveram livre acesso ao alimento.

Os animais que receberam uma refeição por dia a presentaram major área de olho de lombo, do que aqueles que receberam cinco porções diariamente (FRIEND e CUNNINGHAM, 1965, 1967). Esses resultados não concordaram com aqueles obti dos pelos mesmos autores, em 1964.

Quando foi comparado o formecimento à vontade com várias refeições diárias, 1, 2 e 4 (PICKETT et alii, 1964) ou I, 2, 8 e 12 (CROMWELL et alii, 1965), os pesquisadores não constataram variação significativa no característico área de olho de lombo.

A percentagem de pernil na carcaça foi estatisticamente superior ( $P(0,05)$ para os animais que receberam ra ção controlada, comparada com aqueles alimentados à vontade (BABATUNDE et alii, 1966 e STAHLY e WAHLSTROM, 1973). 
o presente experimento foi conduzido nas insta Lações do Setor de Suinocultura, do Departamento de Zootecnia da Escola Superior de Agricultura "Luiz de Queiroz", localiza das no Municipio de Piracicaba, Estado de São Paulo.

Essas instalações são compostas de 12 balas $\operatorname{com} 2,5 \times 3,0 \mathrm{~m}$ de área coberta com telhas de barro e $2,5 \times 4,3 \mathrm{~m}$ de área de solário. As paredes construídas de a venaria de tijolos e o piso inteiramente concretado. As baias são dispostas em 2 alas paralelas de 6 , com o solário na par te interna. Foram utilizadas as 4 baias centrais de cada ala e a limpeza foi feita com lavagens diárias.

Os equipamentos utilizados em cada baia foram os seguintes:

a) comedouro automático feito de madeira, com capacidade para $60 \mathrm{~kg}$ de ração aproximadamente e

b) bebedouro automático tipo chupeta.

0 experimento foi dividido em duas fases: cres cimento - de 24,9 a 61,7 kg e acabamento - de 61,7 a 95,5 kg de peso vivo dos animais.

O delineamento experimental utilizado, para performance de crescimento, foi de blocos ao acaso, usando um 
esquema fatorial $2 \times 2$ (dois tipos de ração e duas formas de arraçoamento), com 4 tratamentos e 4 repetições, perfazendo um total de 16 unidades experimentais ou parcelas. Em cada uni dade experimental foram distribuídos 3 animais, segundo seus pesos, sendo 2 machos castrados e 1 fêmea. O esquema da análise de variância utilizado, conforme PIMENTEL GOMES (1973) • Ka LIL (1974), foi o seguinte:

\begin{tabular}{lccc}
\hline Fontes de & G.L. & S.Q. & Q.M. \\
Variação & $F$ \\
\hline Tipos de ração (R) & 1 & \\
Tipos de fornecimento (F) & 1 \\
R x F & 1 & \\
\hline (Tratamentos) & $(3)$ & & \\
Blocos & 3 \\
Resíduo & 9
\end{tabular}

Total 15

Para avaliar a qualidade da carcaça, foram uti lizados 2 animais de cada unidade experimental, sendo um a fô mea e o outro o macho com o peso mais próximo da média da repe tição.

O delineamento experimental usado também foi o de blocos ao acaso, entretanto, foi utilizado um esquema fato rial $2 \times 2 \times 2$ (dois tipos de ração, duas formas de arraçoamen to e dois sexos), portanto, com 8 tratamentos a 4 repetições, totalizando 32 unidades experimentais. Devido a variação nos pesos finais, foi utilizada a análise de covariância, para a justar a um mesmo peso de abate $(92,47 \mathrm{~kg})$, o peso de todos os animais. D esquema da análise foi, segundo PIMENTEL GOMES (1973), o seguinte: 


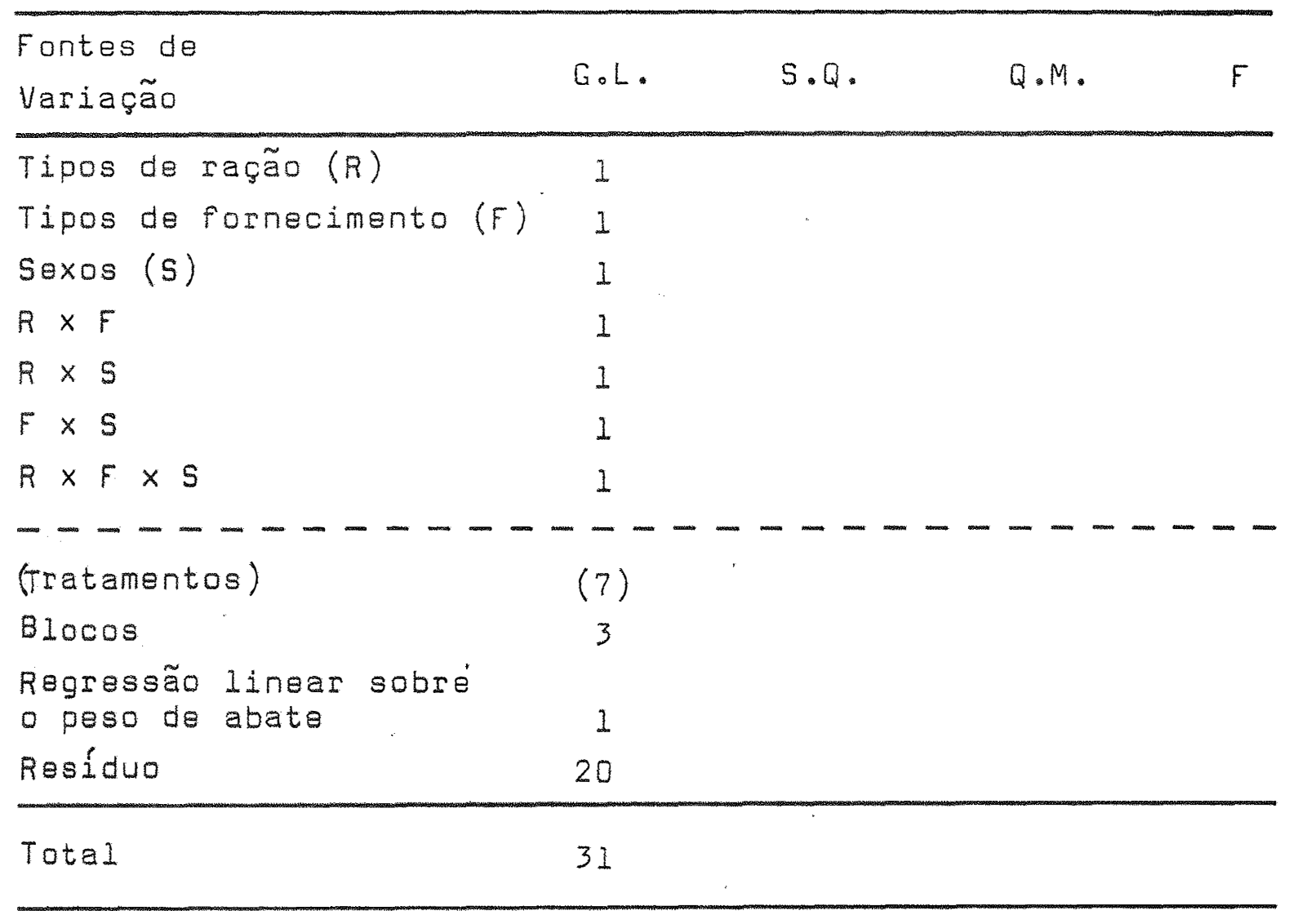

Os tratamentos, distribuídos por sorteio den tro de cada bloco, foram os seguintes:

temunha).

$T_{1}=$ Ração farelada, fornecida à vontade (Tes

$T_{2}=$ Ração granulada, fornecida à vontade.

$T_{3}=$ Ração farelada, controlada e fornecida du as vezes ao dia (7:00 e 17:00 hs.).

$T_{4}=$ Ração granulada, controlada e fornecida duas vezes ao dia (7:00 e 17:00 hs.).

A quantidade de ração, a ser fornecida aos ani mais com alimentação controlada, foi obtida com os dados de consumo de ração à vontade, isto é, a quantidade de ração con 
trolada fornecida estava ao redor de $80-85 \%$ do consumo dos animais alimentados à vontade, na semana anterior.

As rações utilizadas foram obtidas em uma fiI ma comercial e apresentavam $16 \%$ de proteína bruta (PB) na fa se de crescimento e $14 \%$ PB na fase de acabamento.

Na Tabela 1, aparecem as percentagens dos in gredientes nas rações. A energia digestível calculada da rá ção, em Kcal/kg, foi de 3.427 para a ração de crescimento e 3.418 para a ração de acabamento. Para calcular essa energia, foi utilizado os dados das tabelas do NRC (1968).

Tabela l. Composição Percentual das Rações de Crescimento e $A$ cabamento.

Ingredientes

Rações

Crescimento

Acabamento

Milho

70,0

75,0

Farelo de Trigo

8,1

8,3

Far. de Soja Tostado

13,1

10,1

Farinha de Carne

8,0

5,0

Ostras Moídas

-

0,8

Sal

0,4

0,4

Premix Vitamínico-Mineral.

0,4

0,4

Total

100,0

100,0

Os animais usados nesse ensaio foram escolhi dos na própria criação do Departamento de Zootecnia. Eram suí nos puros da raça Landrace, com idade média de 70 dias. Antes de iniciar o experimento, esses leitões foram vermifugados e vacinados contra peste suína. Tiveram um período de adaptação, 
de uma semana, quando receberam a ração testemunha.

0 ganho de peso e o consumo alimentar foram ob tidos semanalmente através da pesagem individual dos suínos, sendo que antes das pesagens, os animais permaneceram em je jum por 20 horas.

Para medir os característicos da carcaça, foi utilizado o Método Brasileiro de Classificação de Carcaça, da ASSOCIAÇÃO BRASILEIRA DE CRIADORES DE SUINOS (1973). DS ani mais antes de serem abatidos, ficaram em jejum por 24 horas, sendo que dessas, as últimas 12 horas permaneceram também em jejum de água. Após o abate, as meias carcaças quentes foram pesadas, e logo em seguida, colocadas na câmara fria, onde es tiveram pelo espaço de 24 horas à temperatura de 2 a $4^{\circ} \mathrm{C}$.

As medidas efetuadas nas carcaças após esse pe ríodo, de 24 horas, na câmara fria foram os seguintes:

a) Peso das meias carcaças frias.

b) Comprimento de carcaça. Tomado do bordo cra neal da sínfise pubiana ao bordo cranio-ventral do atlas.

c) Espessura de toicinho. Foram tomadas 3 medi das: a. na primeira costela, a medida tomada perpendicularmen te à linha dorso-lombar, na altura da porção média da primei ra vértebra toráxica; b. na última costela, obtida na altura da interseção da última vértebra toráxica com a primeira lom bar, perpendicularmente à linha dorso-lombar; c. na última vér tebra lombar, conseguida na altura da articulação da penúlti ma vértebra lombar com a última lombar, perpendicularmente à linha lombar.

d) Olho de lombo e cobertura de gordura corres pondente. o corte para a medida da área de olho de lombo foi feito no mesmo local da medida da espessura de toicinho na úl tima costela, isto é, na altura da articulação da última vér tebra toráxica com a primeira vértebra lombar, perpendicular à linha dorso-lombar. 
e) Peso do pernil. Para obter o corte do per nil, foi serrada a articula̧ão entre a última e a penúltima vértebras lombares, isto é, o mesmo local da medida da espes sura de toicinho na última lombar, perpendicularmente à linha dorsal.

Além dessas medidas, foi obtida ainda, a rela ção carne-gordura, que é a relação entre a área de gordura di vidida pela área de carne; a percentagem de pernil, obtida a través da divisão do peso do pernil pelo peso da carcaça fria correspondente, multiplicada por cem; e ainda, o rendimentode carcaça, que é conseguido através da divisão do peso da carca ça fria, multiplicada por cem, pelo peso de abate. 
5. RESULTADOS E DISCUSSÃO

Os resultados de performance e de qualidade de carcaça obtidos no presente ensaio, são apresentados e discuti dos a seguir.

\subsection{Consumo de ração}

Os consumos totais de ração, dos 3 animais de cada parcela, observados durante o período experimental, são apresentados na Tabela Al, no Apêndice. A Figura l mostra a in fluência dos tratamentos no consumo de alimentos pelos suínos, durante o período experimental.

$$
\text { 5.I.1. Fase de crescimento }
$$

Os consumos médios diários de ração, das repetí ções, nessa fase, são representados na Tabela A2, no Apêndice. A ingestão média diária de ração é mostrada na Tabela 2 e a a nálise de variância desse consumo na Tabela 3.

Nessa fase, o consumo médıo diáriu de ração,não foi significativamente $(P<0,05)$ diferente quando foi testado - tipo de ração (farelada e granulada), apesar do consumo da 
28.

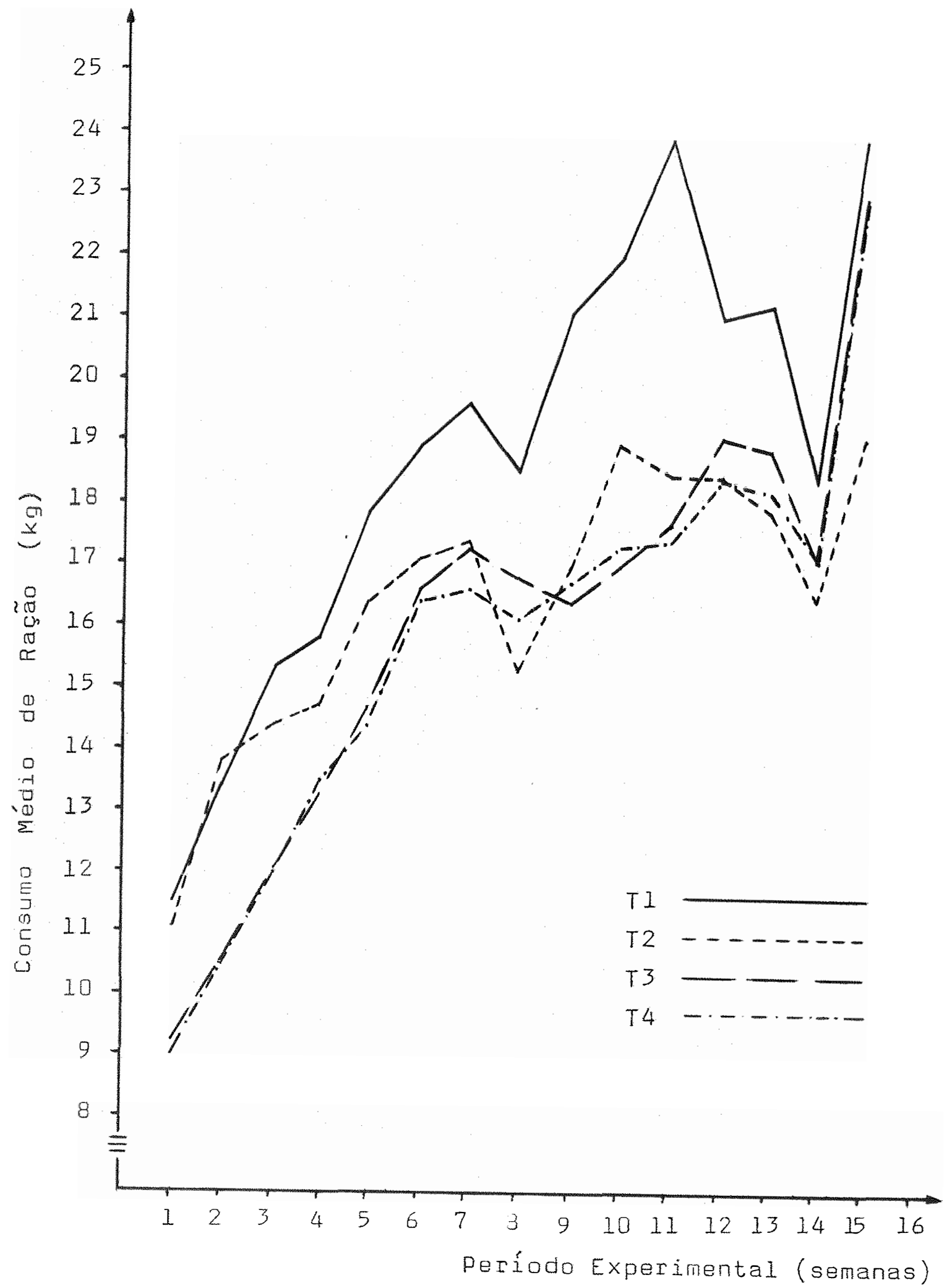

Fiqura 1. Efeitos dos Tratamentos no Consumo de Ra ção pelos Animais 
Tabela 2. Consumos Médios Diários de Ração, na Fase de Cresci mento ( $\mathrm{kg}$ ) (Média de 12 Animais).

\begin{tabular}{|c|c|c|c|}
\hline \multirow{2}{*}{ Ração(R) } & \multicolumn{3}{|c|}{ Fornecimento $(F)$} \\
\hline & À vontade & Controlado & Média \\
\hline Farelada & 2,32 & 1,92 & 2,12 \\
\hline Granulada & 2,15 & 1,89 & 2,02 \\
\hline Média & $2,24^{\mathrm{a}}$ & $I, 91^{b}$ & $(R \times F)^{n \cdot s} \cdot$ \\
\hline
\end{tabular}

Tabela 3. Análise de Variância do Consumo de Ração na Fase de Crescimento.

\begin{tabular}{|c|c|c|c|c|}
\hline $\begin{array}{l}\text { Fontes de } \\
\text { Variação }\end{array}$ & $\begin{array}{l}\text { Graus de } \\
\text { Liberdade }\end{array}$ & $\begin{array}{l}\text { Soma de } \\
\text { Quadrados }\end{array}$ & $\begin{array}{l}\text { Quadrados } \\
\text { Médios }\end{array}$ & $\begin{array}{c}\text { Teste } \\
\text { F }\end{array}$ \\
\hline Ração(R) & 1 & 0,0410 & 0,4410 & 3,80 \\
\hline Fornecimento( $F$ ) & 1 & 0,4323 & 0,4323 & $40,03 * *$ \\
\hline$R \times F$ & 1 & 0,0189 & 0,0189 & 1,75 \\
\hline $\begin{array}{l}\text { (Tratamentos) } \\
\text { (T) - - - }\end{array}$ & $\frac{-\cdots-\cdots}{(3)}$ & $\begin{array}{l}(0,4922) \\
(0,-\cdots\end{array}$ & $\ldots-\cdots$ & $\ldots-\cdots$ \\
\hline Blocos & 3 & 1,1785 & 0,3928 & $36,37 * *$ \\
\hline Resíduo & 9 & 0,0970 & 0,0108 & \\
\hline Total & 15 & $1,7677$. & & \\
\hline
\end{tabular}

** $-P<0,01$.

Coeficiente de Variação $(C \cdot V)=5,02 \%$. 
ração farelada $(2,12 \mathrm{~kg})$ ter sido $4,72 \%$ maior do que o de ração granulada $(2,02 \mathrm{~kg})$. Esse resultado foi semelhante ao obtido por YEN et alii. (1971), que observaram consumo de ração na forma farelada $4,4 \%$ maior do que na forma granulada.

Nessa fase, a interação tipo de ração versus. tipo de fornecimento não foi estatisticamente significativapa ra consumo médio de ração.

5.1.2. Fase de acabamento

o consumo médio diário dos animais de cada tra tamento, na fase de acabamento e a análise de variância des ses consumos, são mostrados nas Tabelas 4 e 5 , respectivamente. No Apêndice, na Tabela A3 estão representadas as inges tões médias diárias de ração, das repetições nessa fase.

Os resultados de consumo obtidos nessa fase, foram inversos àqueles encontrados para a fase decrescimento, isto é, quando o tipo de formecimento (à vontade ou controla do) foi considerado, não houve diferenças estatísticas $(P \angle 0,05)$, apesar de ter havido uma ingestão $7 \%$ maior $(2,74 \mathrm{~kg})$ pelos suínos que receberam ração à vontade comparada com a dos animais com ração controlada (2,55 kg). Os dados de consumo diário reportados por PICKETT et alii, (1963) para suínos com alimentação controlada ou à vontade, também não di feriram significativamente ( $P \angle 0,05)$, entretanto, quando a ração foi fornecida à vontade, houve um consumo maior, pelos animais, da ordem de 12\%. Por outro lado, CRAMPTON et alii. (1954), PICKETT et alii (1964) e STAHLY e WAHLSTROM (1973) ob servaram que o consumo, de suínos que receberam ração à von tade, foi estatisticamente diferente ( $P \angle 0,05)$, quando comparado. com aquele dos animais com alimentação controlada. A diferença de ingestãu de ração fornecida à vontade ou res trita foi de cerca de $18 \%$, sendo maior para os animais com 
Tabela 4. Consumos Médios Diários de Ração na Fase de Acaba mento ( $k g$ ) (Média de 12 Animais).

\begin{tabular}{lccc}
\hline \multirow{2}{*}{ Ração $(R)$} & \multicolumn{3}{c}{ Fornecimento $(F)$} \\
\cline { 2 - 4 } & A vontade & Controlado & Média \\
\hline Farelada & 2,98 & 2,56 & $2,77^{\mathrm{a}}$ \\
Granulada & 2,51 & 2,53 & $2,52^{b}$ \\
Média & 2,74 & 2,55 & $(R \times F)^{\text {n.s. }}$ \\
\hline
\end{tabular}

a e b - Diferença significativa ao nível de $5 \%(P \angle 0,05)$. n.s. - Interação não significativa ao nível de $5 \%(P L 0,05)$.

Tabela 5. Análise de Variância do consumo Alimentar na Fase de Acabamento.

\begin{tabular}{|c|c|c|c|c|}
\hline $\begin{array}{l}\text { Fontes de } \\
\text { Variação }\end{array}$ & $\begin{array}{l}\text { Graus de } \\
\text { Liberdade }\end{array}$ & $\begin{array}{l}\text { Soma de } \\
\text { Quadrados }\end{array}$ & $\begin{array}{l}\text { Quadrados } \\
\text { Médios }\end{array}$ & $\begin{array}{c}\text { Teste } \\
F\end{array}$ \\
\hline Ração（R) & 1 & 0,2550 & 0,2550 & $6,62^{*}$ \\
\hline Fornecimento $(F)$ & 1 & 0,1521 & 0,1521 & 3,95 \\
\hline$R \times F$ & 1 & 0,1892 & 0,1892 & 4,91 \\
\hline $\begin{array}{l}------- \\
(\text { Tratamentos })\end{array}$ & $\begin{array}{c}----- \\
(3)\end{array}$ & $\begin{array}{c}---- \\
(0,5963)\end{array}$ & ---- & --- \\
\hline Blocos & 3 & 0,9286 & 0,3095 & $8,04 *$ \\
\hline Resíduo & 9 & 0,3465 & 0,0385 & \\
\hline Total & 15 & 1,8714 & & \\
\hline
\end{tabular}

* $-p<0,05$

Coeficiente de Variação (C.V.) $=7,43 \%$ 
livre acesso ao alimento.

Na comparação entre os tipos de ração farelada e granulada foram encontradas diferenças significativas ( $P \angle 0,05)$, sendo que os suínos que receberam ração do tipo farelada, apresentaram consumo $9 \%$ maior do que aqueles que re ceberam a ração tipo granulada. Entretanto, autores como YEN et alii (1971), não encontraram diferenças significativas, quanto ao consumo alimentar, quando os tipos de ração foram comparados, apesar do consumo da ração farelada ter sido $6,9 \%$ maior do que o da ração granulada。 Da mesma forma, JENSEN (1966) também não obteve diferenças para o consumo de alimen to, mesmo sendo a ingestão, da ração farelada, superior à gra nulada em $6,6 \%$.

Nessa fase de acabamento, a interação tipo de ração versus tipo de fornecimento também não foi estatística mente significativa $(P<0,05)$.

\subsubsection{Período total}

Para o período total, os consumos médios diá rios de ração,das repetições, são apresentados na Tabela A4, no Apêndice. A ingestão média diária e a análise de variância estão representadas, respectivamente, nas Tabelas 6 e 7 . Como a interação tipos de ração versus tipos de fornecimento foi significativa ( $P<0,05)$, a análise de variância foi desdobra da, para poder estudar melhor essa interação. Essa análise com desdobramento aparece na Tabela 8.

$$
\text { No período total, o consumo de alimento, compa }
$$
rando os tipos de ração, apresentou diferenças significativas ( $P<0,05)$. o consumo diário da ração do tipo farelada $(2,43 \mathrm{~kg})$ foi $7 \%$ maior do que o da ração granulada $(2,26 \mathrm{~kg})$. Os resultudos estão de acordo com os obtidos por CHAMBERLAIN 
Tabela 6. Consumos Médios Diários de Ração no Período Total. (kg). (Miédia de 12 Animais)。

\begin{tabular}{lccc}
\hline & & & Fornecimento $(F)$ \\
\cline { 2 - 4 } & À vonto $(R)$ & Controlado & Média \\
\hline Farelada & 2,63 & 2,23 & $2,43^{c}$ \\
Granulada & 2,32 & 2,20 & $2,26^{d}$ \\
Média & $2,47^{a}$ & $2,21^{b}$ & $(R \times F)^{*}$ \\
\hline
\end{tabular}

a e b - Diferença significativa ao nível de lo ( $\angle 0,01)$. c e d-Diferença significativa ao nível de $5 \%$ ( $\angle 0,05)$. * - Interação significativa ao nível de $5 \%(P \angle 0,05)$.

Tabela 7. Análise de Variância do Consumo Alimentar no Perío do Total.

\begin{tabular}{|c|c|c|c|c|}
\hline $\begin{array}{l}\text { Fontes de } \\
\text { Variação }\end{array}$ & $\begin{array}{l}\text { Graus de } \\
\text { Liberdade }\end{array}$ & $\begin{array}{l}\text { Soma de } \\
\text { Quadrados }\end{array}$ & $\begin{array}{l}\text { Quadrados } \\
\text { Médios }\end{array}$ & $\begin{array}{c}\text { Teste } \\
F\end{array}$ \\
\hline Ração (R) & 1 & 0,1190 & 0,1190 & $7,35 *$ \\
\hline Fornecimento & $F)$ & 0,2704 & 0,2704 & $16,69 * *$ \\
\hline$R \times F$ & 1 & 0,0842 & 0,0842 & $5,20 *$ \\
\hline $\begin{array}{l}------ \\
\text { (Tratanentos) }\end{array}$ & $\begin{array}{c}----- \\
(3)\end{array}$ & $\begin{array}{c}---\cdots \\
(0,4736)\end{array}$ & ---- & --- \\
\hline Blocos & 3 & 0,9045 & 0,3015 & $18,61 * *$ \\
\hline Resíduo & 9 & 0,1459 & 0,0162 & \\
\hline Total & 15 & 1,5240 & & \\
\hline
\end{tabular}

* $\quad-p<0,05$ 。

Coeficiente de Variação $\left(C . V_{.}\right)=5,44 \%$. 
Tabela 8. Análise de Variância, com Desdobramento, do Consumo Alimentar, no Período Total.

\begin{tabular}{|c|c|c|c|c|}
\hline $\begin{array}{l}\text { Fontes de } \\
\text { Variação }\end{array}$ & $\begin{array}{l}\text { Graus de } \\
\text { Liberdade }\end{array}$ & $\begin{array}{l}\text { Soma de } \\
\text { Quadrados }\end{array}$ & $\begin{array}{l}\text { Quadrados } \\
\text { Médios }\end{array}$ & $\begin{array}{c}\text { Teste } \\
F\end{array}$ \\
\hline Ração (R) & 1 & 0,1190 & 0,1190 & $7,35 *$ \\
\hline F. d. Farelada & 1 & 0,3280 & 0,3280 & $20,25 * *$ \\
\hline F.d. Granulada & 1 & 0,0266 & 0,0265 & 1,64 \\
\hline $\begin{array}{l}------- \\
\text { (Tratamentos) }\end{array}$ & $\begin{array}{c}----- \\
(3)\end{array}$ & $\begin{array}{c}----\cdots \\
(0,4736)\end{array}$ & ---- & --- \\
\hline Blocos & 3 & 0,9045 & & \\
\hline Resíduo & 9 & 0,1459 & 0,0162 & \\
\hline Total & 15 & 1,5240 & & \\
\hline
\end{tabular}

* $\quad-p<0,05$

** $-P<0,01$

et alii (1967) os quais também observaram que a ração na. for mafarelada foi a mais consumida pelos suínos, sendo a diferen ça de 9,8\% estatisticamente significativa ( $P L 0,05)$. Em con traste, HINTZ e GARRETT (1967) também encontraram diferenças estatísticas ( $P \angle 0,05)$, da ordem de $7 \%$, no consumo, só que, favorável à ração granulada.Autores como LARSEN e OLDFIELD (1960), BAIRD e MCCULLOUGH (1971) e BAIRD (1973), não acharam diferenças significativas $(P L 0,05)$ no consumo, quando compa raram os tipos de ração, apesar das ingestões da ração farela da terem sido respectivamente 1,$6 ; 3,5$ e $3,6 \%$ superiores. SE ERLEY et alii (1962a) e JENSEN (1966) reportaram diferenças, no consumo, favoráveis à ração granulada de 9,7 e 1,2\%, res pectivamente. No entanto, as diferenças não foram estatistica mente significativas.

o desdotramento efetuado na análise de variân 
cia, mostrou que o tipo de fornecimento à vontade teve um efeito estatisticamente significativo $(P \angle 0,01)$ na melhoriado consumo mas, esse efeito só foi benéfico quando a ração do ti po farelada foi utilizada.

Partindo do princípio de que os suínos conso mem alimentos para se satisfazerem em energia e baseando em LAWRENCE (1971), é possível supor que o menor consumo, dos a nimais que receberam a alimentação na forma granulada, foi de vido a maior quantidade de energia contida nessa ração, isto é, com uma menor quantidade da ração granulada, os suínos sa tisfizeram suas necessidades de energia. Entretanto, com base em BAIRD (1973), que encontrou valóres de energia, maiores pa ra a ração farelada, uma explicação para o maior consumo des se tipo de ração, obsérvado no presente experimento, torna-se mais difícil.

\subsection{Ganho de peso.}

Os pesos médios das parcelas no período experí mental são apresentados na Tabela A5, no Apêndice. Os pesos médios e ganhos médios de feso, referentes aos tratamentos, du rante o período experimental são mostrados na Tabela A6, no $\underline{A}$ pêndice. Esses valores estão representados nas Figuras 2 e 3 , que mostram os efeitos dos tratamentos, respectivamente, no crescimento e no ganho de peso dos suínos durante o período experimental.

\subsubsection{Fase de crescimento}

Os ganhos médios diários de peso, das repetí ções, na fase de crescimerito são apresentados na Tabela A7, no Apêndice. Na Tabela 9 , estão representados os ganhos médios diários, e a respectiva análise de variância é mostrada na Ta bela 10. 
36.

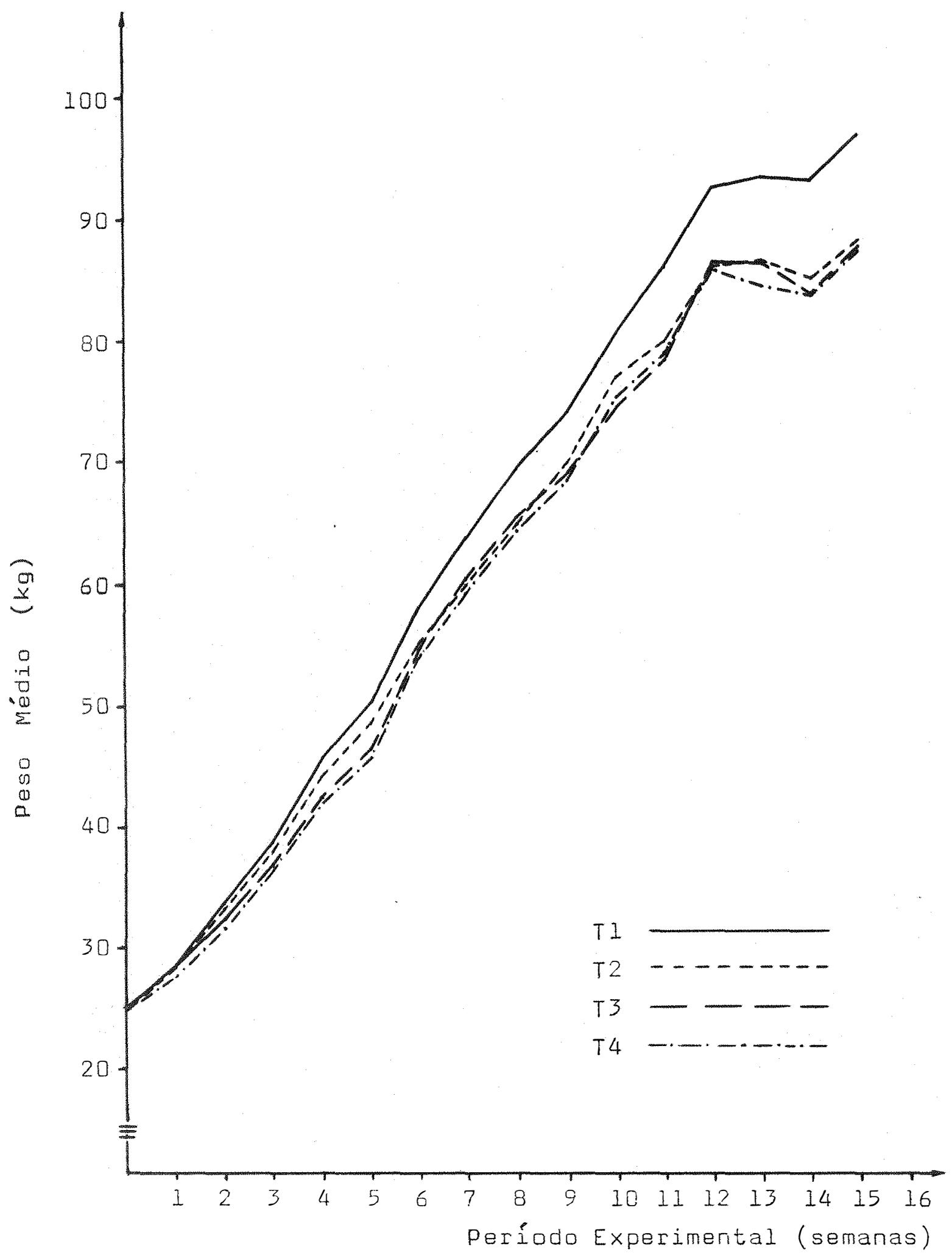

Figura 2. Efeitos dos Tratamentos no Crescimento dos Animais 


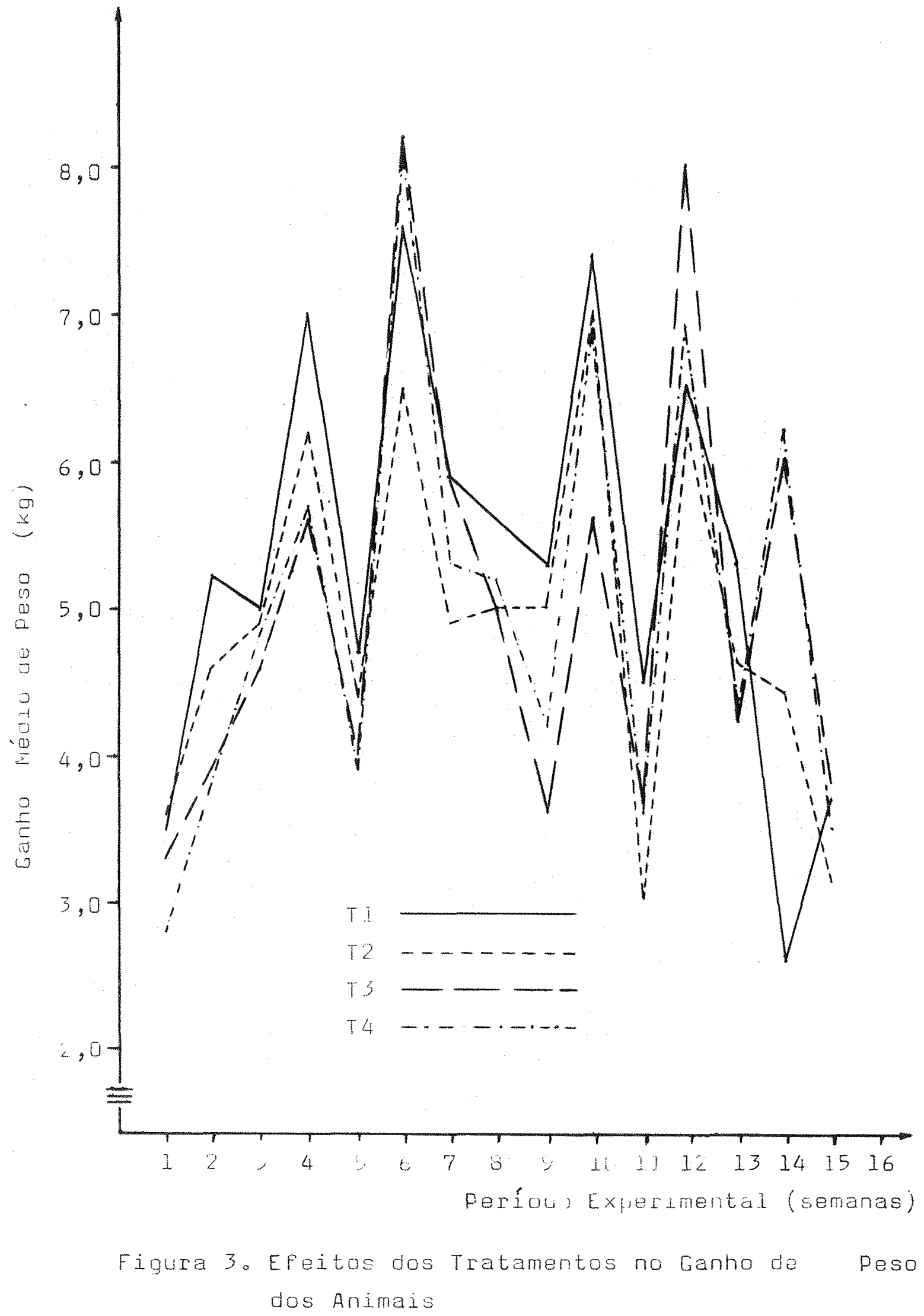


Tabela 9. Ganhos Médios Diários de Peso, na Fase de crescimen to ( $\mathrm{kg}$ ) (Média de 12 Animais).

\begin{tabular}{|c|c|c|c|c|}
\hline \multirow{2}{*}{ Ração $(R)$} & \multicolumn{4}{|c|}{ Fornecimento $(F)$} \\
\hline & $\grave{A}$ & vontade & Controlado & Média \\
\hline Farelada & & 0,792 & 0,722 & $0,758^{a}$ \\
\hline Granulada & & 0,715 & 0,698 & $0,706^{b}$ \\
\hline Média & & 0,754 & 0,710 & $(R \times F)^{n \cdot s \cdot}$ \\
\hline
\end{tabular}

a e b - Diferença significativa ao nível de $5 \%(P \angle 0,05)$. n.s. - Interação não significativa ao nível de 5\% (PL 0,05$)$.

Tabela 10. Análjse de Variância do Ganho de Peso, na Fase de Crescimento.

\begin{tabular}{|c|c|c|c|c|}
\hline $\begin{array}{l}\text { Fontes de } \\
\text { Variação }\end{array}$ & $\begin{array}{l}\text { Graus de } \\
\text { Liberdade }\end{array}$ & $\begin{array}{l}\text { Soma de } \\
\text { Quadrados }\end{array}$ & $\begin{array}{l}\text { Quadrados } \\
\text { Médios }\end{array}$ & $\begin{array}{c}\text { Teste } \\
F\end{array}$ \\
\hline Ração (R) & $I$ & 0,0104 & 0,0104 & $6,12 *$ \\
\hline Fornecimento (F) & 1 & 0,0076 & 0,0076 & 4,47 \\
\hline$R \times F$ & 1 & 0,0028 & 0,0028 & 1,65 \\
\hline $\begin{array}{l}-----\ldots \\
\text { (Tratamentos) }\end{array}$ & $\begin{array}{c}----- \\
(3)\end{array}$ & $\begin{array}{l}(0,0208) \\
(0,0)\end{array}$ & $----\cdots$ & --- \\
\hline Blocos & 3 & 0,0896 & 0,0299 & $17,59 * *$ \\
\hline Residuo & 9 & 0,0150 & 0,0017 & \\
\hline Total & 15 & 0,1254 & & \\
\hline
\end{tabular}

* $\quad-p<0,05$ 。

** $-P \leq 0,01$.

Coeficiente de Variação $\left(C \cdot V_{\bullet}\right)=5,65 \%$. 
o ganho de peso nessa fase, não foi influencia do significativamente $(P L 0,05)$, pelo tipo de formecimento (à vontade e controlado), no entanto, os animais que receberam ração à vontade apresentaram maior ganho, da ordem de $5,8 \%$ $(0,754 \times 0,710 \mathrm{~kg} / \mathrm{dia})$.

Os resultados obtidos por SMIDT et alii (1965) foram semelhantes aos encontrados nesse ensaio. Os ganhos de peso dos animais com a ração fornecida à vontade foram $6,0 \%$ mỉoras que os dos animais com ração controlada, entretanto, a diferença não foi estatisticamente significativa ( $\angle L, 05)$. Autores como CRAMPTON et alii (1954) e PICKETT ot alii. (1964) também não obtiveram resultados estatisticameri te $(P L 0,05)$ diferentes, porém, os ganhos de peso dos ani mais que receberam a ração controlada foram maiores, 3,0 e $5,6 \%$ respectivamente, quando comparados com os dos suinos que foram alimer.tados à vontade.

STAHLY e WAHLSTROM (1973) reportaram uma dife rença significativa $(P<0,05)$ no ganho de peso de suínos, da ordem de $9,8 \%$, favorável à ração fornecida à vontade.

No referente ao tipo de ração (farelada e gramulada), na fase de crescimento, houve uma diferença estatís Lica signıficativa ( $P$ L,05) favorável a ração farelada. Eミ sa diferença foi de $6,9 \%(0,758 \times 0,706 \mathrm{~kg} / \mathrm{dia})$.

A maioria dos experimentos, em que os autores testaram os efeitos dos tipos de ração sobre ganho de peso, encontraram resultados discordantes dos obtidos no presenteen saio. YEN et alii. (1971), quando forneceram uma alimentação a base de milho, na forma granulada ou farelada, não encontraram diferençassignificativas para ganho de peso, mas a medida que glútem de milho era introduzido na dieta,substituindo paI cialmente o milho, o ganho de peso dos suinos recebendo a ra ção granulada foi maior. Em média, esses autores encontraram um ganho de peso, estatisticamente $(P L 0,05)$, maior para os 
animais alimentados com a ração granulada contendo 10,20 ou $30 \%$ de glútem substituindo milho.

BRAUDE e ROWELL (1966) e PERRY (1972) reportä ram, respectivamente, ganhos de peso 4,8 e 6,2\% maiores para os suínos que receberam a ração na forma granulada; essas di ferenças foram estatisticamente significativas ( $P(0,01)$.

Numa revisão feita por JENSEN (1966), foram a presentados resultados que mostraram um ganho de peso $2,6 \%$ maior para os animais que foram alimentados com a ração fare lada. Entretanto, na mesma revisão, são citados resultados em que não houve diferença, quanto a ganho de peso na comparação das duas formas de ração, na fase de crescimento.

A interiação, entre os tipos de ração e os ti pos de formecimento, não foi estatisticamente $(P \angle 0,05)$ dife rente.

\subsubsection{Fase de acabamento}

Na Tabela A8, no Apêndice, são apresentados os ganhos médios diários de peso, das repetições, nessa fase. Os ganhos médios diários são apresentados na Tabela ll, e a Tabe la 12 mostra a análise de variância dos mesmos.

O tipo de formecimento à vontade ou controlado não apresentou diferenças estatisticas ( $\mathrm{P} L 0,05)$, pois o ga nho diário de peso foi praticamente igual (0,730 e 0,731 kg) para os animais que receberam ração à vontade e controlada, respectivamente.

Os resultados obtidos nesse experimento estão de acordo com aqueles reportados por STAHLY e WAHLSTROM (1973). Da mesma forma, PICKETT et alii (1963) e CROMWELL et alii. (1965) também não encontraram diferenças significativas, apesar dos animais que receberam a ração à vontade terem apre 
Tabela 11. Ganhos Médios Diários de Peso na Fase de Acabamen to ( $\mathrm{kg}$ ) (Média de 12 Animais).

\begin{tabular}{lccc}
\hline \multirow{2}{*}{ Ração $(R)$} & \multicolumn{3}{c}{ Fornecimento $(F)$} \\
\cline { 2 - 4 } & A vontade & Controlado & Média \\
\hline \multirow{2}{*}{ Farelada } & 0,755 & 0,720 & 0,738 \\
Granulada & 0,705 & 0,742 & 0,724 \\
Média & 0,730 & 0,731 & $(R \times F)^{\text {n.s. }}$ \\
\hline
\end{tabular}

nos. Interação não significativa ao nível de $5 \%(P<0,05)$.

Tabela 12. Análise de Variância do Ganho de Peso, na Fase de Acabamento.

\begin{tabular}{|c|c|c|c|c|}
\hline $\begin{array}{l}\text { Fontes de } \\
\text { Variação }\end{array}$ & $\begin{array}{l}\text { Graus de } \\
\text { Liberdade }\end{array}$ & $\begin{array}{l}\text { Soma de } \\
\text { Quadrados }\end{array}$ & $\begin{array}{l}\text { Quadrados } \\
\text { Médios }\end{array}$ & $\begin{array}{c}\text { Teste } \\
F\end{array}$ \\
\hline $\operatorname{Ração~(R)~}$ & 1 & 0,0008 & 0,0008 & 0,30 \\
\hline Fornecimento $(F)$ & 1 & 0,0001 & 0,0001 & 0,04 \\
\hline$\frac{R \times F}{\text { (Tratamentos) }}$ & $-\frac{1}{(3)}-$ & $\frac{0,0051}{(0,0060)}$ & $\begin{array}{r}0,0051 \\
----1\end{array}$ & 1,89 \\
\hline B1ocos & 3 & 0,1958 & 0,0653 & $24,18 * *$ \\
\hline Resíduo & 9 & 0,0239 & 0,0027 & \\
\hline Total & 15 & 0,2257 & & \\
\hline
\end{tabular}

** $-P<0,01$.

Coeficiente de Variação $\left(C \cdot V_{\cdot}\right)=7,12 \%$ 。 
sentado maior ganho de peso ( 5,5 e $2,0 \%$ respectivamente).

Por outro lado, autores como CRAMPTOM 브 alii (1954), PICKETT et alii (1964), BABATUNDE et alii (1966) o KLAY et alii (1969) reportaram ganhos de peso, significativa mente, maiores para os suínos que receberam a ração fornecida à vontade, quando comparada com a ração controlada. As diferen ças de g:n nhodiário de peso apresentadas por esses autores fo ram de 19,$0 ; 19,6 ; 35,0$ ө $29,0 \%$, respectivamente。

No presente ensaio os animais que receberam ra ção farelada, apesar de apresentarem maiores ganhos diários de peso $(0,738 \mathrm{~kg})$, não diferiram estatisticamente $(P \angle 0,05)$ da queles que tiveram acesso à ração granulada $(0,724 \mathrm{~kg})$. Esses resultados estão de acirdo com aqueles obtidos por LARSEN $\theta$ OLDFIELD (1960), BRAUDE \& ROWELL (1966) e YEN et alii (1971).

Entretanto, autores como HINTZ a GARRETT (1967), HANKE at alii (1972) e PERRY (1972) encontraram, respectivamen te, ganhos de peso 12,$6 ; 5,6$ e 8,6\% maiores para os suínos que receberam a raçãe na forma granulada, quando comparadacom a ração farelada.

\subsubsection{Período total}

Us ganhos médios diários, das repetições no pe ríodo total, estäo representados na Tabola A9, no Apêndice. Os ganhos médios diários, no período total, são apresentados na Tabela 13 e a análise de variância na Tabela 14 .

A interação tipo de ração versus tipo de forne cimento, foi significativa $(P L 0,05)$, e por isso foi feito um desdobramento da análise de variância, a qual é apresentada na Tabela 15.

A comparação entre os ganhos de peso dos ani mais cujas rações foram fornecidas à vontade $(0,740 \mathrm{~kg})$ e con 
Tabela 13. Ganhos Médios Diários de Peso, no Período Total (kg) (Média de 12 Animais).

\begin{tabular}{lccc}
\hline \multirow{2}{*}{ Ração $(R)$} & \multicolumn{3}{c}{ Fornecimento $(F)$} \\
\cline { 2 - 4 } & À vontade & Controlado & Média \\
\hline Farelada & 0,772 & 0,718 & 0,745 \\
Granulada & 0,708 & 0,722 & 0,715 \\
Média & 0,740 & 0,720 & $(R \times F)^{*}$ \\
\hline
\end{tabular}

* - Interação significativa ao nível de 5\% ( $\angle 0,05)$ 。

Tabela 14. Análise de Variância do Ganho de Peso no Período Total。

\begin{tabular}{|c|c|c|c|c|}
\hline $\begin{array}{l}\text { Fontes de } \\
\text { Variação }\end{array}$ & $\begin{array}{l}\text { Graus de } \\
\text { Liberdade }\end{array}$ & $\begin{array}{l}\text { Soma de } \\
\text { Quadrados }\end{array}$ & $\begin{array}{l}\text { Quadrados } \\
\text { Médios }\end{array}$ & $\begin{array}{c}\text { Teste } \\
F\end{array}$ \\
\hline Ração（R） & I & 0,0036 & 0,0036 & 4,00 \\
\hline Fornecimento & (i) 1 & 0,0016 & 0,0016 & 1,78 \\
\hline$R \times F$ & $I$ & 0,0049 & 0,0049 & $5,44 *$ \\
\hline $\begin{array}{l}(\text { Tratamentos) } \\
\text { (Tra }\end{array}$ & $\frac{----}{(3)}$ & $\begin{array}{r}------ \\
(0,0101)\end{array}$ & ---- & $--\cdots$ \\
\hline Blocos & 3 & 0,1268 & 0,0423 & $47,00 * *$ \\
\hline Resíduo & 9 & 0,0085 & 0,0009 & \\
\hline Total & 15 & 0,1454 & & \\
\hline
\end{tabular}

$*-p<0,05$.
$* *-p<0,01$.

Coeficiente de Variação ( C.V.) $=4,11 \%$. 
Tabela 15. Análise de Variância, com Desdobramento, do Ganho de Paso, no Paríodo Total.

\begin{tabular}{|c|c|c|c|c|}
\hline $\begin{array}{l}\text { Fontes de } \\
\text { Variação }\end{array}$ & $\begin{array}{l}\text { Graus de } \\
\text { Liberdade }\end{array}$ & $\begin{array}{l}\text { Soma de } \\
\text { Quadrados }\end{array}$ & $\begin{array}{l}\text { Quadrados } \\
\text { Médios }\end{array}$ & $\begin{array}{c}\text { Teste } \\
F\end{array}$ \\
\hline Ração (R) & 1 & 0,0036 & 0,0036 & 4,00 \\
\hline F.d. Farelada & 1 & 0,0060 & 0,0060 & $6,67 *$ \\
\hline F. d. Granulada & 1 & 0,0004 & 0,0004 & 0,44 \\
\hline $\begin{array}{l}-------- \\
\text { (TIatamentos) }\end{array}$ & $\begin{array}{c}----- \\
(3)\end{array}$ & $\begin{array}{r}---- \\
0,0100\end{array}$ & ----- & ---- \\
\hline Blocos & 3 & 0,1268 & & \\
\hline Resíduo & 9 & 0,0085 & 0,0009 & \\
\hline Total & 15 & 0,1454 & & \\
\hline
\end{tabular}

* $\quad-p<0,05$.

trolada $(0,720 \mathrm{~kg})$ não mostrou diferenças ostatísticas ( $p<0,05)$, entretanto os animais que receberam a ração à von tade, apresentaram ganho de peso $2,7 \%$ maior.

SMIDT et alii (1965) quando restringiram a ra ção, obtiveram ganhos de pesos $6 \%$ menores que dos suínos com alimentação à vontade, no entanto, essa diferença não foi es tatisticamente significativa。

Os resultados, obtidos nesse ensaio, discordam daqueles reportados por BRAUDE et alii (1958), SMOLINSKY et alii (1963), PICKETT et alii (1964) e STAHLY e ' WAHLSTROM (1973), que encontraram ganhos de pesos significativamente ( $P$ L 0,05) maiores para os suínos que foram alimentados com a ração fornecida à vontade. Essas diferenças foram de 16,8; 16,$6 ; 9,8$ e $13,9 \%$, respectivamente. 
A análise estatística dos tipos de ração, não mostrou diferenças estatisticamente significativas ao nível de 5\% de probabilidade, apesar da ração farelada ter pro piciado ganho diário de peso $4 \%$ maior que a ração granulada. CHAMBERLAIN et alii. (1967), NCR-42 COMMITTEE ON. SWINE NUTRITION (1969), TRIBBLE et alii (1973) e DANIELSON (1976) também não encontraram diferenças significativas, quando com pararam os tipos de ração, embora os ganhos de pesos dos ani mais que receberam a ração granulada fossem 1,7 a $6,0 \%$ supé rior aos dos suínos que foram alimentados com a ração farela da.

Entretanto, CONRAD e BEESON (1958), SEERLEX et alii. (1962a), GILL e OLDFIELD (1965), BRAUDE e ROWELL (1966), HINTZ E GARRETT (1.967), BAIRD E MCCULLOUGH (1971) e BAIRD (1973) verificaram que na comparação dos tipos de ração, a granulada foi estatisticamente superior à farelada, no referente aos ganhos de pesos dos animais.

A análise de variância desdobrada, indicou que - tipo de formecimento teve efeito significativo $(P L 0,05)$ no ganho de peso, mas somente quando a ração era do tipo farelado. Nesse caso, o tratamento que apresentou maior ganho de pe so foi aquele em que foi fornecida ração farelada àvontade.

Provavelmente, o maior ganho de peso dos suí nos, que receberam ração farelada à vontade, foi devido ao ma ior consumo de ração, observado nesse tratamento. No entanto, embora o consumo de ração granulada controlada,tenha sidoesta tisticamente inferior ao da ração farelada à vontade, os res pectivos ganhos de peso correspondentes, não diferiram signi ficativamente. Isso pode ser explicado pelo maior aproveita mento da ração granulada controlada. o melhor aproveitamento da ração granulada pode ser devido a maior absorção e retenção de nitrogênio (JENSEN e BECKER, 1965 e YEN et alii,1971), enquanto a melhor utilização da ração controlada pode ser de vido ao maior tempo de retenção do alimento no trato intestí 
nal do suíno (CASTLE e CASTLE, 1956 e 1957 e SEERLEY et alii 1962b).

\subsection{Conversão alimentar}

As conversões alimentares médias, das parcelas, no decorrer do período experimental, são apresentadas na Tabe la Alo, no Apêndice. A Figura 4 mostra os efeitos dos trata mentos sobre a conversão alimentar.

\subsubsection{Fase de crescimento}

$\mathrm{Na}$ Tabela 16 estão representadas as conversões alimentares médias na fase de crescimento. A respectiva aná lise de variância é mostrada na Tabela 17. A Tabela All, no A pêndice, apresenta as conversões médias das repetições na fa se de crescimanto.

Tabela 16. Conversões Alimentares Médias na Fase de Crescimen to (kg de ração/kg de ganho) (Média de 12 Animais).

\begin{tabular}{|c|c|c|c|c|}
\hline \multirow{2}{*}{ Ração (R) } & \multicolumn{4}{|c|}{ Fornecimento $(F)$} \\
\hline & $\grave{A}$ & vontade & Controlado & Média \\
\hline Farelada & & 2,92 & 2,65 & 2,78 \\
\hline Granulada & & 3,00 & 2,70 & 2,85 \\
\hline Média & & $2,96^{\mathrm{a}}$ & $2,67^{b}$ & $(R \times F)^{n \cdot S \cdot}$ \\
\hline
\end{tabular}

a e b - Diferenças significativas ao nível de $1 \%(P \angle 0,01)$. n.s. - Interação não significativa ao nível de 5\% (PL 0,05$)$. 


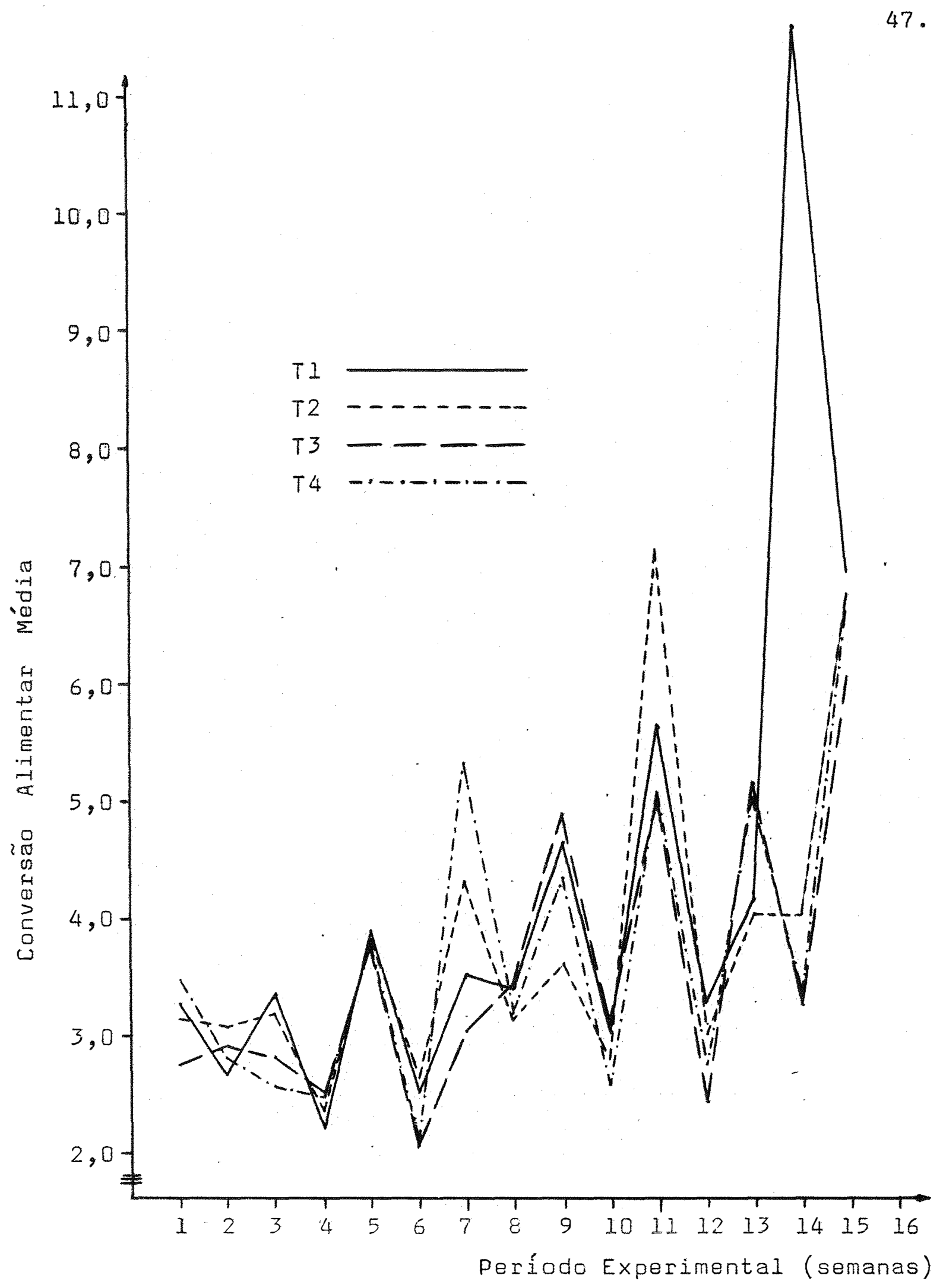

Figura 4。Efeitos dos Tratamentos na Conversão Alimen tar dos Animais 
Tabela 17. Análise de Variancia da Conversão Alimentar na Fa se de Crescimento.

\begin{tabular}{|c|c|c|c|c|}
\hline $\begin{array}{l}\text { Fontes de } \\
\text { Variação }\end{array}$ & $\begin{array}{l}\text { Graus de } \\
\text { Liberdade }\end{array}$ & $\begin{array}{l}\text { Soma de } \\
\text { Quadrados }\end{array}$ & $\begin{array}{l}\text { Quadrados } \\
\text { Médios }\end{array}$ & $\begin{array}{c}\text { Teste } \\
F\end{array}$ \\
\hline Ração (R) & 1 & 0,0162 & 0,0162 & 3,12 \\
\hline Fornecimento & $(F)$ & 0,3334 & 0,3334 & $64,12 * *$ \\
\hline$R \times F$ & 1 & 0,0008 & 0,0008 & 0,15 \\
\hline $\begin{array}{l}------ \\
(\text { Tratamentos })\end{array}$ & $\begin{array}{c}----- \\
(3)\end{array}$ & $(0,3504)$ & ---- & --- \\
\hline BIocos & 3 & 0,1393 & 0,0464 & $8,92 *$ \\
\hline Resíduo & 9 & 0,0466 & 0,0052 & \\
\hline Total & 15 & 0,5363 & & \\
\hline
\end{tabular}

$* \quad-P<0,05$.
$* * 10,01$.

Coeficiente de Variação (C.V.) $=2,56 \%$ 。

A análise de variância efetuada demonstrouque, apesar dos suínos que receberam ração farelada terem apresen tado melhor conversão $(2,78)$, esta não foi diferente estatis ticamente $(P<0,05)$ da conversão obtida com ração granulada $(2,85)$. Os resultados obtidos nesse experimento são concordan tes com aqueles encontrados por YEN et alii. (1971), que tam bém não verificaram diferenças na conversão alimentar devido aos tipos de ração.

Entretanto, BRAUDE e ROWELL (1966), JENSEN (1966) e PERRY (1972) verificaram que a eficiência de conver são foi estatisticamente $(P \angle 0,05)$ superior para os animais que receberam a ração na forma granulada.

A conversão alimentar dos animais que consumi 
ram ração controlada $(2,67)$, foi estatisticamente $(p<0,01)$ superior à daqueles recebendo ração à vontade $(2,96)$, sendo a diferença igual a $9,8 \%$. STAHLY e WAHLSTROM (1973) encontra ram uma conversão $9,6 \%$ melhor para os suinos que tiveram a ra ção em quantidades controladas, entretanto, não houve diferen ça significativa ao nível de $5 \%$ de probabilidade. PICKETT et alii (1964) e SMIDT et alii (1965) também não acharam diferen ças estatísticas quando compararam a ração fornecida à vonta de e controlada, pois as conversões alimentares foram pratica mente iguais.

\subsubsection{Fase de acabamento}

As conversões alimentares médias diárias, das repetições, na fase de acabamento, são mostradas na Tabela A12, no Apêndice. Nas Tabelas 18 e 19, são apresentadas, res pectivamente, as conversões alimentares médias e a análise de variância dessas conversões, na fase de acabamento.

Tabela 18. Conversões Alimentares Médias na Fase de Acabamen to (kg de ração/kg de ganho) (Média de 12 Animais).

\begin{tabular}{|c|c|c|c|}
\hline \multirow{2}{*}{ Ração (R) } & \multicolumn{3}{|c|}{ Fornecimento (F) } \\
\hline & À vontade & Controlado & Média \\
\hline Farelada & 4,03 & 3,58 & $3,80^{\mathrm{C}}$ \\
\hline Granulada & 3,58 & 3,43 & $3,50^{d}$ \\
\hline Média & $3,80^{\mathrm{a}}$ & $3,50^{b}$ & $(R \times F)^{n \cdot s}$ \\
\hline
\end{tabular}


Tabela 19. Análise de Variância da Conversão Alimentar na Fa se de Acabamento.

\begin{tabular}{lcccc}
\hline $\begin{array}{l}\text { Fontes de } \\
\text { Variação }\end{array}$ & $\begin{array}{c}\text { Graus de } \\
\text { Liberdade }\end{array}$ & $\begin{array}{c}\text { Soma } \\
\text { Quadrados }\end{array}$ & $\begin{array}{c}\text { Quadrados } \\
\text { Médios }\end{array}$ & $\begin{array}{c}\text { Teste } \\
F\end{array}$ \\
\hline Ração (R) & 1 & 0,3570 & 0,3570 & $8,11^{*}$ \\
Fornecimento (F)I & 0,3630 & 0,3630 & $8,25^{*}$ \\
R X F & 1 & 0,0856 & 0,0856 & 1,94 \\
--- & --1 & $(0,8056)$ & & \\
(Tratamentos) & $(3)$ & 0,9900 & 0,3300 & $7,50 *$ \\
Blocos & 3 & 0,3964 & 0,0440 & \\
Resíduo & 9 & 2,1920 & & \\
\hline Total & 15 & & \\
\hline
\end{tabular}

* $\quad-P<0,05$.

Coeficiente de Variação $\left(C \cdot V_{\cdot}\right)=5,75 \%$.

A conversão alimentar dos animais que recebe ram ração granulada $(3,50)$ diferiu estatisticamente $(P \angle 0,05)$ daquela dos suínos alimentados com ração farelada $(3,80)$, sen do, 7,9\% melhor. BRAUDE \& ROWELL (1966), HANKE at alii (1972) e PERRY (1972) encontraram melhoria de 3,$6 ; 6,4$ e $9,6 \%$ nas conversões alimentares de suínos que receberam a ração granu lada. Essas diferenças foram estatisticamente $(P \angle 0,05)$ sig nificativas. HINTZ e GARRETT (1967) e YEN et alii. (1971), en tretanto, não encontraram diferenças estatisticamente $(P / 0,05)$ significante nas conversões alimentares, apesar dos animais com ração granulada apresentarem conversões ligeiramente me Ihores. Em contraste, LARSEN e OLDFIELD (1960) verificaram que a conversão alimentar média dos súinos alimentados com a ração farelada foi estatisticamente $(P L 0,05)$ melhor do que a obtida com ração granulada $(3,37 \times 3,71)$. 
Quando foram comparados os tipos de fornecimen to de ração, os animais que receberam a ração controlada apre sentaram melhor conversão alimentar. $(3,50)$ que aqueles com ra ção à vontade $(3,80)$, sendo que a diferença de $7,9 \%$ foi esta tisticamente significativa $(P L 0,05)$. Esses resultados estão de acordo com os obtidos por MEADE et alii. (1964). KLAY et alii, (1969) verificaram que as conversões dos animais que re ceberam ração à vontade foi de 3,98 e as daqueles com ração controlada 3,55 , portanto $11 \%$ melhor para a alimentação con trolada. Essa diferença, entretanto, não foi estatisticamente significativa.

Dutros autores, como CRAMPTON 브 alii (1954), 8ECKER ot alii. (1963); PICKETT ot alii (1963 e 1964) e. STAHLY e WAHLSTROM (1973), também não encontraram diferenças signifi cativas, quanto a conversão alimentar, quando compararam os tipos de formecimento (à vontade e controlado). No entanto, BABATUNDE et alii (1966) reportaram conversão estatistica mente melhor ( $P \angle 0,05)$ para os animais que receberam ração à vontade.

\subsubsection{Período total}

As conversões alimentares médias no período to tal (crescimento e acabamento) são apresentadas na Tabela 20; e a Tabela 21 mostra a análise de variância dessas conversões. $\mathrm{Na}$ Tabela Al3, no. Apêndice, são mostradas as conversões alimentares médias, das repetições, no período total.

No período total, os animais que receberam ra ção granulada apresentaram melhor conversão alimentar $(3,16)$ do que aqueles que foram alimentados com ração farelada $(3,26)$. A diferença foi significativa ao nível de 5\% de proba bilidade. DANIELSON (1976), não verificou diferenças signifi cativas nas conversões alimentares dos animais que receberam 
Tabela 20. Conversões Alimentares Médias, no Período. Total (kg de ração/kg de ganho)(Média de 12 Animais)。

$\operatorname{Ração~(R)~}$

Fornecimento $(F)$

À vontade Controlado Média

Farelada

3,42

3,09

$3,26^{\mathrm{c}}$

Granulada

3,28

3,05

$3,16^{d}$

Média

$3,35^{\mathrm{a}}$

$3,07^{b}$

$(R \times F)^{n \cdot S 。}$

a e b - Diferentes estatisticamente ( $\angle 0,01)$ 。

c e d-Diferentes estatisticamente $(P<0,05)$ 。

n.s. - Interação não.significativa ao nível de 5\% (PL 0,05)。

Tabela 21. Análise de variância da Conversão Alimentar no Pe ríodo Total.

\begin{tabular}{|c|c|c|c|c|}
\hline $\begin{array}{l}\text { Fontes de } \\
\text { Variação }\end{array}$ & $\begin{array}{l}\text { Graus de } \\
\text { Liberdade }\end{array}$ & $\begin{array}{l}\text { Soma de } \\
\text { Quadrados }\end{array}$ & $\begin{array}{l}\text { Quadrados } \\
\text { Médios }\end{array}$ & $\begin{array}{c}\text { Teste } \\
F\end{array}$ \\
\hline Ração (R) & 1 & 0,0342 & 0,0342 & $5,26 *$ \\
\hline Fornecimento & $(F) I$ & 0,3025 & 0,3025 & $46,54 * *$ \\
\hline $\begin{array}{l}R \times F \\
\frac{P}{(\text { Tratamentos })}--\end{array}$ & $-\frac{1}{(3)}$ & $\begin{array}{c}0,0111 \\
-\frac{-11}{(0,3478)}\end{array}$ & $\begin{array}{c}0,0111 \\
---1-\end{array}$ & $\begin{array}{c}2,71 \\
---\end{array}$ \\
\hline Blocos & 3 & 0,0826 & 0,0275 & 4,23 \\
\hline Resíduo & 9 & 0,0588 & 0,0065 & \\
\hline
\end{tabular}

* $-P<0,05$ 。

** - P L 0,01 .

Coeficiente de Variação $\left(c . V_{.}\right)=2,51 \%$ 。 
ração granulada ou farelada. Entretanto, outros autores, CON RAD e BEESON (1958), SEERLEY et alii (1962a), GILL e OLDFIELD (1965), BRAUDE e ROWELL (1966), CHAMBERLAIN et alii. (1967), NCR-42 COMMITTEE ON SWINE NUTRITION (1969), BAIRD \& MCCULLOUGH (1971), BAIRD (1973) e TRIBbLe et alii. (1973), verificaram que as conversões alimentares dos suínos alimentados com a ração granulada foram estatisticamente superiores àquelas de ani mais ingerindo ração farelada. Essa diferença, favorável a ra ção granulada, variou de 3 a $10 \%$.

Uma diferença estatística altamente significa tiva ( $(0,01$ ) apareceu quando o tipo de ração foi testado . Usando a ração com o fornecimento controlado, os animais apre sentaram melhor conversão $(3,07)$ em comparação com o forngci mento à vontade $(3,35)$, sendo de $8,4 \%$ a diferença。 Esses re sultados estão em desacordo com os obtidos por CROMWELL et alii (1965), pois, apesar de não mostrar diferenças estatísti cas, os suínos alimentados com ração à vontade apresentaram conversões que foram $6 \%$ melhores do que a daqueles recebendo alimentação controlada. Outros autores, porém, verificaram que a conversão alimentar dos animais que receberam ração con trolada foi superior, apesar de não diferirem estatisticamen te (SMOLINSKY et alii, 1963 ; PICKETT et alii, 1964 e STAHLY e WAHLSTROM, 1973). Entretanto, BRAUDE et alii. (1958) encon traram conversões alimentares dos suínos que receberam a ra ção controlada, estatisticamerte ( $P(0,05)$, superiores àque las dos animais alimentados com a ração à vontade.

Como fode ser observadc na Tabela 20 , a conver são alimentar média doe animais que foram alimentados com a ração granulada e controlada, foi a melhor $(3,05)$, apesar da quela dos suínos que receberam ração farelada e controlada $(3,09)$, ter sido apenas $1,3 \%$ pior.

Segundo a literatura, diversas causas poderiam explicar a melhor eficiência de utilização de alimentos peios suinos que receberam ração granulada e controlada. Uma 
delas diz respeito as modificações físicas ou químicas das ra ções no decorrer do processo de peletização. Durante o proces so, pode ter ocorrido a gelatinização parcial do amido, fazen do com que a fração carboidrato tornasse mais susceptível à ação enzimática (JENSEN e BECKER, 1965; JENSEN, 1966 e BAIRD, 1973)。

Outra explicação para o ocorrido, pode ter si do a redução do teor de fibra da ração, quando o processo de peletiza,ção foi utilizado (LARSEN e OLDFIELD, 1960 e JENSEN e BECKER, 1965).

JENSEN e BECKER (1965) e YEN et alii, (1971) ve rificaram que quando a ração era granulada, havia maior absor ção e retenção de nitrogênio. Dessa forma, com uma maior quantidade desse elemento sendo absorvido e retido, maior quantidade de proteína poderá ser elaborada,o que resultará em maior ganho de peso.

Quando uma restrição alimentar é imposta aos suínos, o tempo de permanência desse alimento no trato intes tinal é aumentado, err. relação aos animais que recebem a ração à vontade (CASTLE e CASTLE: 1956 e 1957 e SEERLEY et alii 1962b)。Como o alimento permanece mais tempo no trato gastro intestinal, ele poderá ser melhor aproveitado, porque haverá uma melhor digestão desse alimento e uma melhor absorção de nutrientes.

\subsection{Qualidade da carcaça}

As médias das características da carcaça dos animais estão representadas na Tabela 22. A análise de variân cia ajustada, dessas características é apresentada na Tabela 23. Nas Tabelas A14, Al5, Al6 e Al7 são mostradas, respectiva mente, as características das carcaças nos tratamentos TI, T2, T3 e T4。 


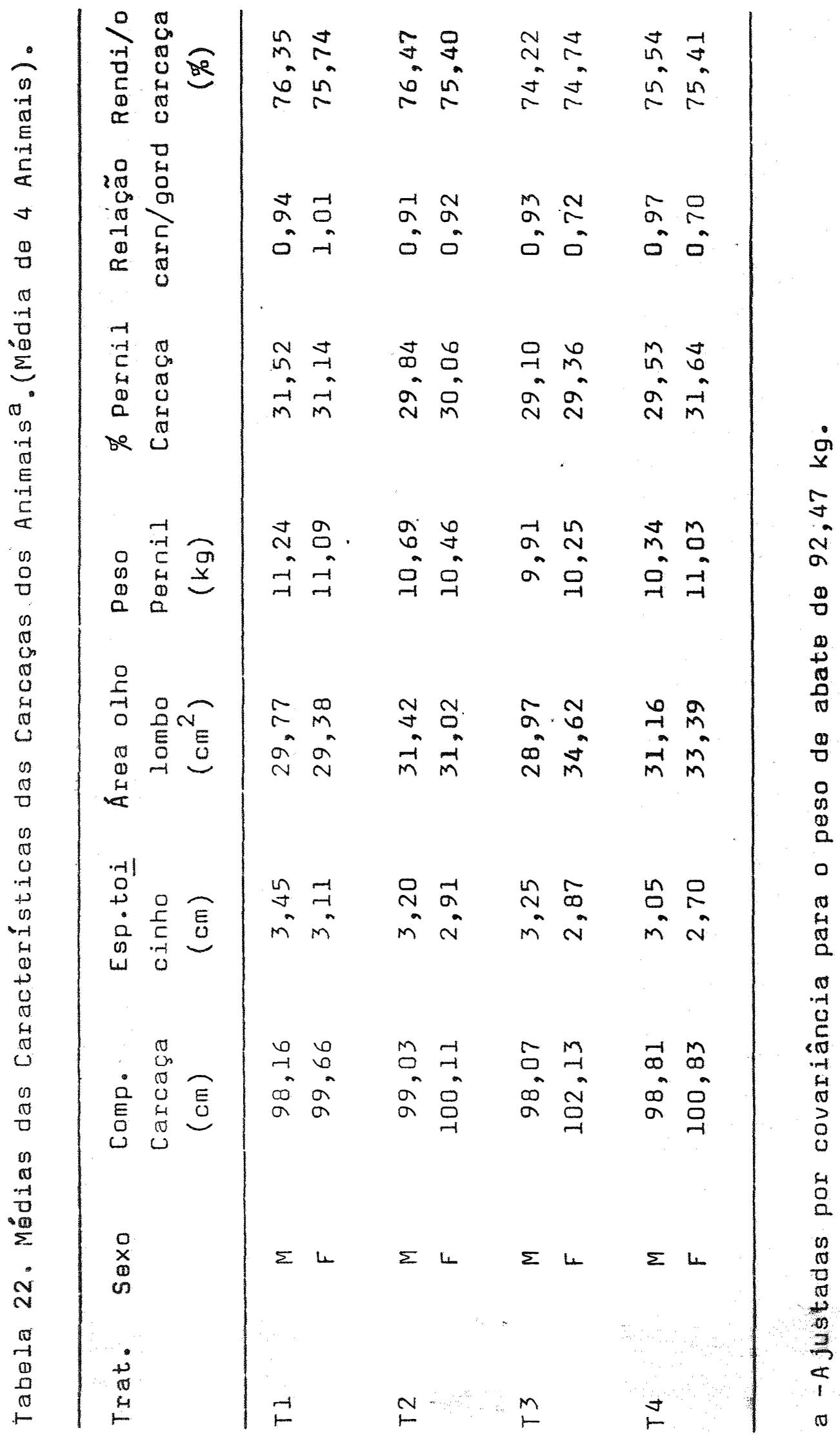


56.

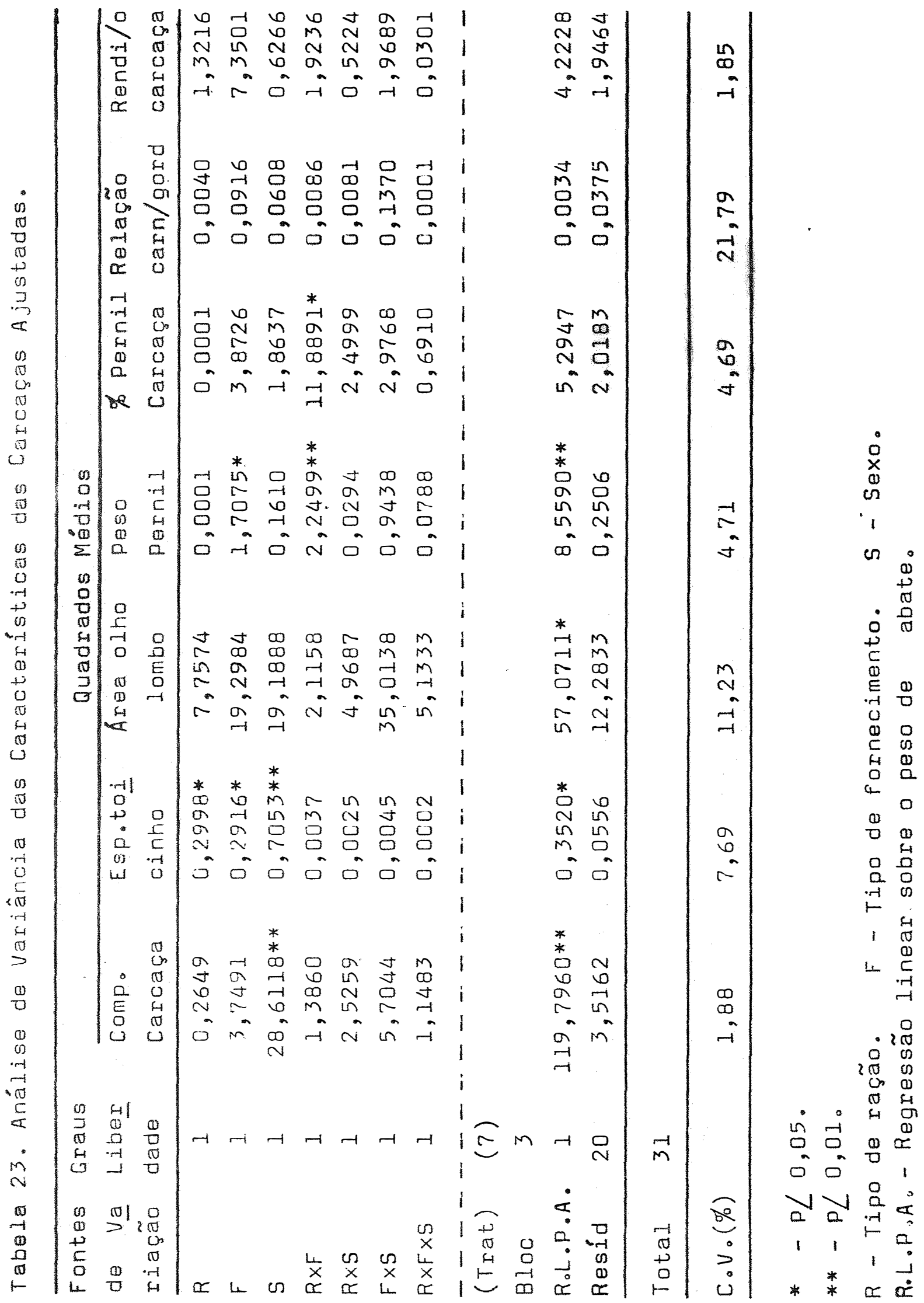




\subsubsection{Comprimento de carcaça}

Não houve efeito significativo dos tipos de ra ção sobre os comprimentos das carcaças, que foram $99,70 \mathrm{~cm} e$ $99,50 \mathrm{~cm}$ para os animais com ração granulada e farelada, res pectivamente. Esse resultado está de acordo com BRAUDE e RO WELL (1966), HINTZ e GARRETT (1967), BAIRD E MCCULLOUGH (1971), BAIRD (1973) e DANIELSON (1976), que também não verificaram diferenças significativas, devido ao tipo de ração, no compri mento da carcaça。,

o tipo de forrecimento de ração à vontade ou controlado também não resultou em diferença estatística sịgni ficativa no comprimerito de carcaça $(99,24 \mathrm{~cm}$ e $99,96 \mathrm{~cm}$, res pectivamente). Os resultados desse ensaio concordam com aque les obtidos por PICKETT et alii (1963), STOTHERS (1963), CROM WELL et alii.(1965), KLAY et alii (1969) e STAHLY e WAHLSTROM (1973)。

Quando os comprimentos das carcaças foram ana lisados, para determinar efeito de sexo, foram observadas di ferenças estatísticas significativas ( $P \angle O, 01)$, sendo as car caças das fêmeas mais compridas que as dos machos (I00,68 x 98,52 cmi). Esse resultado concorda com aquele obti do por BAIRD (1973), que também encontrou diferenças signifi cativas ( $P \angle 0,01)$ favorável às fêmeas.

Não foi possível obter uma explicação para es ses resultados.

5.4.2. Espessura de toicinho

A análise de variância mostrou que a espessura de toicinho dos animais que receberam ração granulada ( $2,96 \mathrm{~cm}$.) foi estatisticamente ( $P \angle 0,05)$ menor que a dos suános com ra ção farelada $(3,17 \mathrm{~cm})$. BAIRd e McCullough (1971) concordaram, 
em parte, com esses resultados, isso porque, encontraram ani mais com espessura de toicinho $3,5 \%$ menor quando receberam ra ção granulada, entretanto, essa diferença não foi significati va. DANIELSON (1976) não encontrou diferenças estatísticas nas espessuras de toicinho, quando comparou ração granulada e farelada. Por outro lado, as espessuras de toicinho observadas POI HINTZ e GARRETT (1967) e BAIRD (1973), foram respectiva mente 6,3 e 2,0\% menores para os suínos que receberam a ração farelada em comparação com a granulada. As diferenças não fo ram, entretanto, estatisticamente significativas.

Para o tipo de fornecimento, as resultados fo ram favoráveis aos animais que receberam a ração controlada, isto $\dot{\theta}$, os toicinhos dos suínos alimentados con ração controlada apresentaram menores éspessuras $(2,97 \mathrm{~cm})$ que os animais com ração ad libitum $(3,17 \mathrm{~cm})$. A diferença foi estatistica mente significativa $(P \angle 0,05)$. Esses resultados estão de a cordo com aqueles obtidos por BABATUNDE et alii (1966), KLAY et alii (1969) e STAHLY e WAHLSTROM (1973), os quais, também, verificaram que os animais, com a dieta controlada, apresenta ram menor ( $\mathrm{P} L 0,05$ ) espessura de toicinho. Outros autores, co mo PICKETT et alii (1963), SMOLINSKY et alii (1963), STOTHERS (1963), CROMWELL et alii (1965) e PICKETT et alii. (1964), ob tiveram resultados semelhantes, mas as diferenças não foram significativas estatisticamente.

Quanto ao sexo, as fêmeas apresentaram menor espessura de toicinho $(2,90 \mathrm{~cm})$ do que os machos $(3,24 \mathrm{~cm})$ e essa diferença foi altamente significativa ( $P \angle 0,01)$. Da mes ma forma, BAIRD (1973) verificou que houve diferença estatís tica $(P<0,01)$ entre sexo, sendo que as fêmeas apresentaram toicinho de menor espessura. 


\subsection{3. Área de olho de lombo}

As áreas de olho de lombo das carcaças dos suí nos não diferiram estatisticamente, em função do tipo de ra ção recebido. Os olhos de lombo apresentaram áreas de 30,68 e $31,75 \mathrm{~cm}^{2}$, para os uínos alimentados com ração farelada e gra nulada, respectivamente.

Os resultados obtidos no presente ensaio estão de acordo com aqueles relatados por HINTZ e GARRETT (1967), BAIRD e MCCLLLOUGH (1971), BAIRD (1973) e DANIELSON (1976)。

No estudo do tipo de fornecimento de ração,tam bém, não foram encontradas diferenças estatísticas significa tivas para área de olho de lombo. Entretanto, os lombos dos animais que receberam alimentação controlada apresentaram á reas ligeiramente maiores do que aquelas dos suínos recebendo ração à vontade $\left(32,04 \mathrm{e} 30,40 \mathrm{~cm}^{2}\right)$. SMOLINSKY et alii (1963), STOTHERS (1963), CROMWELL et alii. (1965), PICKETT et alii (1964), KLAY et alii (1969) e STAHLY e WAHLSTROM (1973) também verificarar que não havia variação significativa nesse característico da carcaça, quando testaram a ração fornecida à vontade e controlada. BABATUNDE et alii. (1966), entretanto, reportaram maior $(P<0,05)$ área de olho de lombo, para os suínos que receburam a ração controlada, em comparação com a ração fornecida à vontade.

Os sexos não influenciaram significativamente a área de olho de lombo, apesar das fêmas apresentarem uma área de Lombo, em média, 5,5\% maior do que a dos machos $(32,10$ $\left.\times 30,33 \mathrm{~cm}^{2}\right)$. BAIRD (1973) verificou que esse caracteristico foi 7,0\% maior para as fêmeas e que essa diferença foi esta tisticamente $(P L 0,01)$ significativa。 
Os pesos dos pernis dos animais alimentados com ração farelada $(10,62 \mathrm{~kg})$ nãoforam estatisticamente diferentes da queles dos suínos que receberam a ração granulada $(10,63 \mathrm{~kg})$ 。 Esse resultado está de acordo com aquele reportado por DANI ELSON (1976), que também não encontrou diferenças significati vas, para o tipo de ração (farelada e granulada).

o peso médio de pernil, dos animais que recebe rami a ração fornecida à vontade $(10,87 \mathrm{~kg})$, foi estatisticamen te ( $P(0,05)$ maior do que aquele dos suínos com ração restri ta $(10,38 \mathrm{~kg})$. Esse resultado discorda daquele obtido por B BATUNDE et alii, (1966), os quais verificaram que os animais, a limentados com ração controlada, apresentaram maior ( $\angle 0,05$ ) peso médio de pernil do que aqueles com ração à vontade.

$$
\text { Não houve efeito significativo de sexo sobre o }
$$

peso de pernil, sendo que os pesos foram $10,54 \mathrm{~kg}$ para os ma chos e 10,71 kg para as fêmeas.

A interação, tipo de ração versus tipo de forne cimento, foi estatisticamente significativa ( $P L O, 01)$. Portan to, foi efetuado um desdobramento na análise de variância, que é apresentado na Tabela 24.

A análise desdobrada indicou que o tipo de for necimento somente foi significativo ( $P(O, 01)$, quando foi uti lizada a ração na forma farelada e o melhor tipo de fornecimen to foi o ad libitum.

\subsubsection{Percentagem de pernil na carcaça}

As percentagens de pernil na carcaça não foram estatisticamente diferentes quando os suínos receberam ração farelada $(30,28 \%)$ ou granulada $(30,27 \%)$. BAIRD (1973) também 
Tabela 24. Análise de Variância, com Desdobramento, dos Pesos dos Pernis Ajustados.

\begin{tabular}{|c|c|c|c|c|}
\hline $\begin{array}{l}\text { Fontes de } \\
\text { Variação }\end{array}$ & $\begin{array}{l}\text { Graus de } \\
\text { Liberdade }\end{array}$ & $\begin{array}{l}\text { Soma de } \\
\text { Quadrados }\end{array}$ & $\begin{array}{l}\text { Quadrados } \\
\text { Médios }\end{array}$ & $\begin{array}{c}\text { Teste } \\
F\end{array}$ \\
\hline Ração (R) & 1 & 0,0001 & 0,0001 & 0,0004 \\
\hline F.d. Farodada & 1 & 3,4491 & 3,4491 & $13,76 *$ \\
\hline F.d. Granulada & 1 & 0,0459 & 0,0459 & 0,18 \\
\hline Saxo & 1 & 0,1610 & 0,1610 & 0,64 \\
\hline$R \times S$ & 1 & 0,0294 & 0,0294 & 0,12 \\
\hline$F \times S$ & 1 & $0,9.438$ & 0,9438 & 3,77 \\
\hline$R \times F \times S$ & 1 & 0,0788 & 0,0788 & 0,31 \\
\hline $\begin{array}{l}------- \\
\text { (Tratamento) }\end{array}$ & ---- & ---- & ---- & --- \\
\hline Blocos & 3 & & & \\
\hline \multicolumn{5}{|c|}{ Regressão sobre o } \\
\hline Peso de Abato & 1 & & & \\
\hline Residuo & 20 & 5,0110 & 0,2506 & \\
\hline
\end{tabular}

Total

** $-\mathrm{p} L \mathrm{0}, 01$.

não encontrou diferenças significativas entre os tipos de ra ções, quando esse característico foi analisado.

Quando as percentagens de pernil na carcaça fo ram analisadas para determinar o efeito do tipo de fornecimen to de ração, também não foram observadas diferenças estatisti cas significativas, apesar dos animais que receberam ração à vontade berem apresentado maior percentagem de pernil na car caça, do que aqueles alimentados com ração controlada $(30,64$ $\times 29,91 \%)$. Esse resultado não concorda com aqueles obtidos por 
BABATUWDE et alii (1966) e STAHLY e WAHLSTROM (1973) os quais verificaram que quando a ingestão dos animais foi controlada, eles apresentaram uma percentagem do pernil em relação a car caça estatisticamente $(P<0,05)$ maior do que quando a ração foi formecida ad libitum.

Da mesma forma, não houve diferença estatísti ca quando as percentagens de pernil na carcaça foram testa das para sexo, apesar das fêmeas apresentarem ligeira vanta gem sobre os machos $(30,55 \times 30,00 \%)$. BAIRD (1973) verificou que as fêmeas apresentaram percentagons de pernil na carcaça, estatisticamente ( $P<O, O I)$, maiores do que as dos machos.

A interação tipo de ração versus tipo de for necimento foi estatisticamente significativa $(P<0,05)$ pára esse característico. Por essa razão foi feito o desdobramerto da análise de variância a qual é mostrada na Tabela 25.

Os dados da análise de variância mostraram di ferença estatística ( $P L 0,05)$ significativa para o tipo de fornecimento dentro de ração farelada. A ração farelada à von tade foi a que apresentou melhor percentagem de pernil na car caça, além de maior peso de pernil, conforme visto anterior mente.

\subsubsection{Relação carne-gordura}

A relação carne-gordura não foi significativa para nenhuma fonte de variação. Entretanto, a ração farelada resultou numa relação $3,6 \%$ maior do que a ração granulada $(0,90 \times 0,88)$. Isso significa que os animais que receberam ra ção farelada apresentaram carcaças mais ricas em gordura e que os suinos alimentados com ração granulada produziram car caças de melhor qualidade, com maior teor de carne.

No referente ao tipo de fornecimento, a relação carne-gordura dos suínos que forarn alimentados ad libitum 
Tabela 25. Análise de Variância, com Desdobramento, das Per centagens de Pernil na Carcaça.

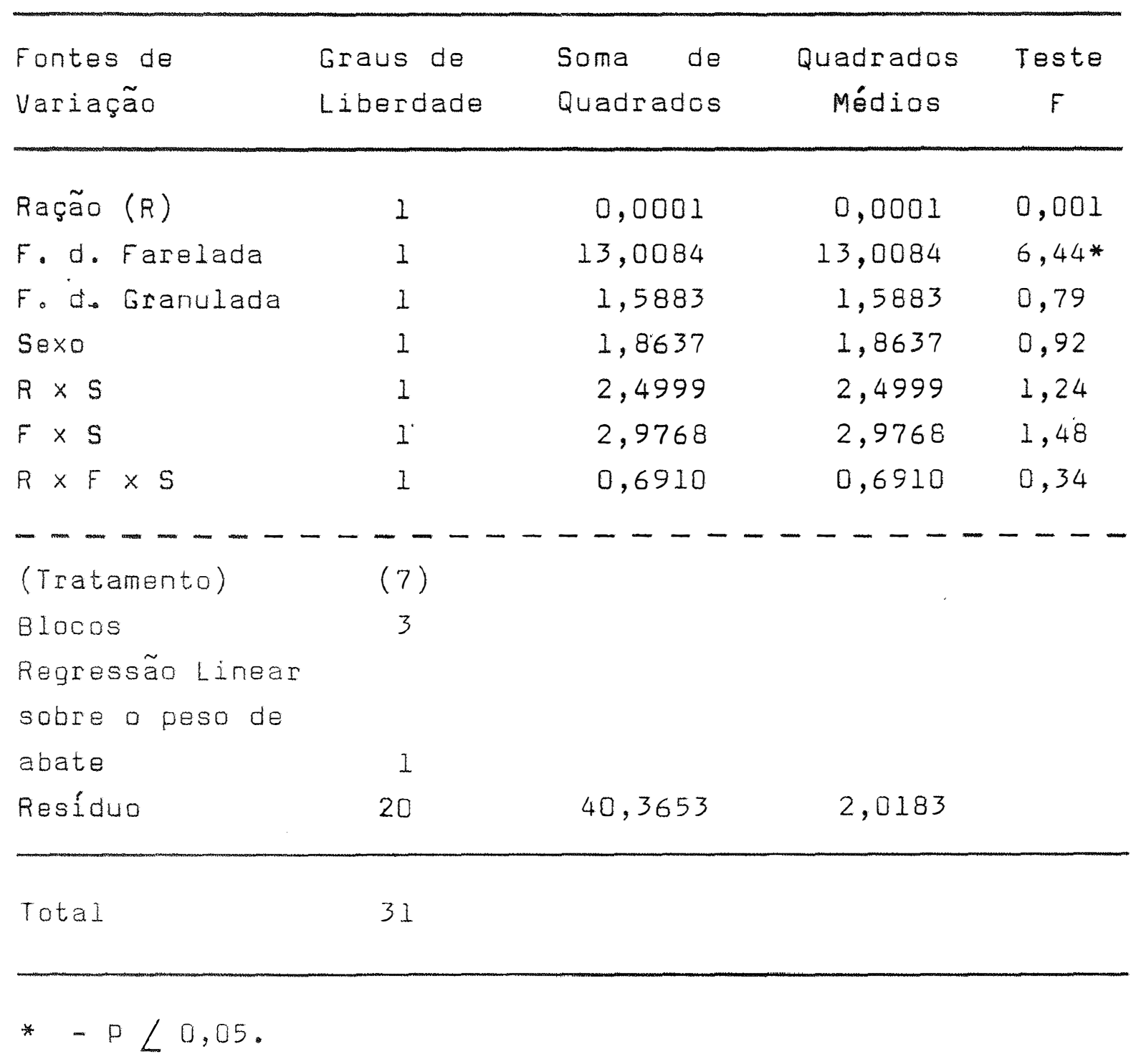


$(0,94)$ foi $12,6 \%$ maior do que aqueles que receberam a ração controlada $(0,83)$, evidenciando que os animais aos quais foi restringida a ingestão, apresentaram maior percentual de carne em relação à gordura, na carcaça.

Apesar dos efeitos de sexo também não terem si do estatisticamente significativo, as fêmeas apresentaram ma ior quantidade de carne $(11,8 \%)$, na carcaça, que os machos, visto que as relações carne-gordura foram 0,83 e 0,94, respec tivamente para fêmeas e machos.

\subsubsection{Rendimento de carcaça}

A análise de variância mostrou que para o tipo de ração, o rendimento de carcaça não foi estatisticamente a fetado $(75,26$ e $75,70 \%$, respectivamerte para raça farelada e granulada)。

Esse resultado está de acordo com BRAUDE e RD WELL (1966) e BAIRD (1973) que também não verificaram diferen ças significativas no rendimento de carcaça, dos suinos ali mentados com ração fareiada ou controlada.

Da mesma forma, o rendimento de carcaça não poi, estatisticamerte diferente, quando os tipos de forneci montos foram testados. Entretanto os animais alimentados à vontade apresentaram rendimento ligeiramente maiores que os dos suínos que tiverarn alimertação controlada ( 75,99 ×74,98\%)。 PICKETT et alii. (1964), CRUMWELL et alii (1965) e STAHLy e WAHLSTROM (1973) estudando o rendimento de carcaça, também não encontraram diferença estatística devido ao tipo de forneci mento de ração.

Os machos apresentaram rendimentos de carcaça $(75,64 \%)$ maior do que as fêmeas $(75,32 \%)$, entretanto, essa di ferença não foi estatisticamente significativa. Esse resulta do concorda com aquele obtido por BAIRD (1973). 
6. CONCLUSÕES

Com base nos resultados obtidos nesse experi mento, foi possível chegar as conclusões que vem a seguir.

Fase de crescimento:

a) ó tratamento Tl (ração farelada à vontade) foi o que apresentou melhor ganho médio diário de peso $(0,792 \mathrm{~kg}$ ), vindo a seguir os tratamentos T3 (ração farelada controlada - 0,722 kg), T2 (ração granulada à vontade - 0,715 kg) e T4 (ração granulada controlada - 0,698 kg).

b) As melhores conversões alimentares foram ob tidas pelos suínos que receberam as rações controladas, T3 $(2,65)$ e T4 $(2,70)$.

Fase de acabamento:

a) Os tratamentos Tl e T4 apresentaram os me Lhores ganhos diários médios de peso, 0,755 e 0,742 kg respec tivamente, seguidos dos tratamentos $\mathrm{T3}(0,720 \mathrm{~kg})$ e $(0,705 \mathrm{~kg})$. 
b) A melhor conversão alimentar nessa fase foi obtida pelos animais que.receberam a ração granulada, forneci da 2 vezes ao dia $(3,43)$ 。

Período total:

a) A forma de arraçoamento que resultou em maior ganho de peso foi aquela que usou ração do tipo farela da, com o fornecimento à vontade (TI). Com essa dieta, o ga nho diário médio de peso obtido pelos suínos foi de 0,772 kg.

b) A ração granulada com fornecimento controlado ( 14 ) permitiu aos suínos apresentarem a melhor conversão alimentar $(3,05)$ 。

Qualidade de carcaça:

a) O comprimento da carcaça só foi afetado pelo sexo, sendo as fêmeas mais compridas que os machos.

b) A espessura de toicinho foi menor com a ra ção granulada do que com a farelada, e a alimentação controla da foi superiora ad libitum. As fêmeas apresentaram menor es pessura de toicinho que os machos. Aparentemente, o tratamento T4 (ração granulada e controlada) foi aquele que resultou em menor espessura de toicinho. Essa melhoria foi, em relação aos tratamentos Tl, T2 eT3, de 16,$6 ; 4,7$ e 5,4\%, respectiva mente。

c) O melhor peso de pernil foi obtido pelos suínos do tratamento Tl (ração farelada e à vontade) que foi 13,0, 16,6 e 10,6\% superior aos dos tratamentos T2, T3 e T4, respectivamiente.

d) A área de olho de lombo, a relação carne gordura e o rendimentos de carcaça não foram estatisticamente afetados pelos tratamentos utilizados. 
Forty eight Landrace pigs were used to study, the influence of feed form and feed management on growing and fini shing performance and carcass quality. The animals received a corn-soybean mixture with $16 \%$ crude protein in the growing phase $(24.9$ to $61.7 \mathrm{~kg})$ and $14 \%$ crude protein in the finishing phase $(61.7$ to $95.5 \mathrm{~kg})$, supplied according to the following treatments combinations:

TI - Meal ration fed ad libitum。

T2 - Pelleted ration fed ad libitum。

T3 - Meal ration, restricted feeding (about $85 \%$ ad libitum) twice daily。

T4 - Pelleted ration, restricted feeding (about $85 \%$ ad libitum) twice daily。

The experiment was designed according to a ran domized block with four replications of three animals. Statis tical analysis follued a $2 \times 2$ ( 2 forms and 2 supplies) facto rial scheme for the performance data and a $2 \times 2 \times 2$ ( 2 forms, 2 supplies and 2 sexes) for carcass data.

The treatments TI, T2, T3 and T4 showed an ave rage daily gain of $0.772,0.703,0.718,0.722 \mathrm{~kg}$, an average 
daily feed consumption of $2.63,2.32,2.23,2.20 \mathrm{~kg}$ and a ave rage feed efficiency of $3.42,3.28,3.09,3.05$, respectivily。 The animals receiving $T l$ showed better $(P L 0.05)$ average daily gain than the others. Pelleted ration increased the feed effi ciency $(P L 0.05)$ as compared with meal rations. Restricted fee ding independently of ration types showed $(P L 0.05)$ greater feed efficiency relatively to ad libitum.

$$
\text { Carcass back fat was reduced significantly }
$$

$(P L 0.05)$ by pelleted rations when compared with meal rations independently of the supply, and by the restricted feeding com pared with ad libitum independently of the ration type. Res tricted pelleted ration determined the best ham weight. Loin eye area, dressing percent and meat-fat relation did not show significant differences among the treatments。 
8. LITERATURA CITADA

ASSOCIAÇÃO BRASILEIRA.DE CRIADORES DE SUÍnOS, Estrela, 1973。. Método Brasileiro de . Classificação de Carcaças. Publica ção Técnica no 2。

BABATUNDE, G.M., W.G. PON'D, L.D. VAN VLECK, G.H. KROENING, J. T.REID, J.R. STOUFFER e G.H. WELLINGTON, 1966. Relation ships among some physical and chemical parameters of ifull versus limited-fed Yorkshire pigs slaughtered at different live weights. J。An. Sci. Albany, 25:526-531。

BAIRD, D.M. e M.E. McCULLOUGH, 1971. Effects of pelleted ra tions for growing-finishing pigs。 J. An。Sci. Albany, 32: 370 (abstr).

BAIRD, D.M., 1973. Influence of pelleting swine diets on metabolizable energy, growth and carcass characteristics. J.An. Sci. Albany, 36:516-521。

BECKER, D。E。, A.H. JENSEN, B。G。HARMON, H.W. NORTON e B.C. BREIDENSTEIN, 1963. Effect of restricted diet on the performance of finishing pigs。 J.An. Sci。 Albany. $\underline{22}$ : 1116 (abstr). 
BECKER, D.E., A.H. JENSEN, B.G. HARMON E H.W. NORTON, 1964. Factors affecting the response of the pig to a restricted dietary intake. J.An. Sci. Albany, 23:1206 (abstr).

BRAUDE, $R_{0,9}, M_{0} J$. TOWNSEND, G. HARRINGTON \& J.G. ROWELL, 1958. A large scale test of the effects of food restriction on the performance of fattening pigs. J.Agric. Sci. Cam bridge, 51:208-217.

BRAUDE, R., M.J. TOWNSEND, G. HARRINGTON E J.G. ROWELL, 1963. A comparison of feeding growing pigs once or twice daily. J.Agric。Sci. Cambridge, 60:389-391。

BRAUDE, R. e J.G. ROWELL, 1966. Comparison of meal and pellet for growing pigs fed either in troughs or off the floor. J.Agric。Sci. Cambridge, 67:53-57.

BRooks, Po, 1975. Feeding methods. Pig Farming. Londres, agos to, 96.

CASTLE, E.J. e M.E。 CASTLE, 1956. The rate of passage of food through the alimentary tract of pigs.J.Agric. Scio Cam bridge, 47: 196-203.

CASTLE, E。]。 e MoE。CASTLE, 1957。 Further studias of the rate of passage of food through the alimentary tract of pigs. 3. Agric。Sci. Cambridge, 49:106-112.

CHAMBERLAIN, C.C., G.M. MERRIMAN, E.R. LIDVALL \& C.T. GAMBLE, 1967. Effects of feed processing method and diet form on the incidence of esophagogastric ulcers in swine. J.An. Sci.Albany, 26:72-75. 
CONRAD, J.H. e W.M. BEESON, 1958. Pellets vs. meal vs. freechoice as methods of feedings growing-finishing swine. Lafayette, Purdue University。 4p. (Mimeo.A.S.240).

CRAMPTON, E.W., G.C.ASHTON e L.E。LLOYD, 1954. The effect of restricting feed intake of market hogs during the fini shing period on the quality of bacon carcass. J. An.Sci. Albany, 13:321-326.

CROMWELL, G.L。, R.A.PICKETT, J.R.FOSTER e R.M.PEART, 1965 。 Effect of frequency of feeding on performance and carcass characteristics of suine。Lafayette, Purdue University 。 5p. (Research Progress Report 202).

DANIELSON, D.M., 1976. Dietary protein level and form for gro wing-finishing pigs. J。An. Sci. Albany, 42:1349 (abstr).

ENGLAND, D.C. J.E。 OLDFIELD, T.P. DAVIDSON E R.W。COOPER, 1965. Pelleted vs. meal barley rations for full or limi tedmfed pigs. J.An. Sci。Albany, 24:597 (abstr)。

FRIEND, O.W. e H.M. CUNNINGHAM, 1964。 Effects of feeding fre quancy on metabolism, rate and efficiency of gain and on carcass quality of pigs。 JoNutrition。 Philadelphia, 83: $251-256$.

FRIEND, DoW。 e H.M。 CUNNINGHAM, 1965。 Growth and carcass sty dies uith pigs fed once or five times daily. J.An. Scio Albany, 24:880 (abstr)。

FRIEND, D.W. e H.M. CUNNINGHAM, 1967. Growth, carcass, blood and fat studies with pigs fed once or five times daily。 J.An: Sci. Albany, 26:316-332. 
GILL, D。R。 e J.E。 OLDFIELD, 1965. Effects of pelleting and addition of fat-to.high barley rations on rate and effici ency of gains of swine.J. An. Sci. Albany, 24:599 (abstr).

HANKE, H。E。, J.W。RUST, R.J. MEADE E L。E. HANSON, 1972. Infl lu ence of source of soybean protein, and of pelleting, on rate of gain and gain/feed of growing swine. J. An. Sci. Albany, 35:958-962。

HINTZ, HoF。 e WoN。GARRETT, 1967. Steam pressure processing and pelleting of barley for growing-finishing swine. J.An。 Sci。Albany, 26:746-748。

JENSEN, A.H。 e D.E. BECKER, 1965. Effect of pelleting diets and dietary components on the performance of young pigs。 3. An. Sci。 Albany, 24:392-397.

JENSEN, A.H., 1966. Pelleting rations for swine. Feedstuffs, Minneapolis, 38 (31):24。

KALIL, E.B., 1974。 Princípios de Técnica Experimental com Ani. mais. Piracicaba, (s。edo)。210p。

KLAY, R.F。, G.C.SMITH e M.G。WELLER, 1969. Effect of restric ted feed intake on performance, carcass measurements, fla vor and tenderness of Hampshire and Palouse swine。 J.An。 Sci。Albany, 28:417-422.

LARSEN, L.M。 e J.E. OLDFIELD, 1960。 Improvement of barley ra tions for swine. I I Effect of pelleting and supplementa tion with barley malt, JoAn. Sci. Albany, 19:601-606. 
LAWRENEE, T.L.J., 1971. Cubing the diet of the growing pig: Some effects on nutritive value of temperature, pressure and physical form. J. Sci.Fd Agric。 London, 22:403-406.

MEADE, R.J०, H.E。 HANKE, M०E. TUMBLESON, D。 WASS E L.E. HAN SON, 1964. Effects of feed restrition and protein intake on performance of market hogs。 J.An. Sci. Albany, 23: 1201 (abstr)。

NICHOLSON, R.S。, 1976. Cubing and pelleting. Pig Farming。 Lon dres, maio, 95 .

NCR-42 COMMITTEE ON SWINE NUTRITION, 1969. Cooperative regio nal studies with growing swine: Effects of source of in gredients, form of diet and location on rate and efficien cy of gain of growing swine. J. An. Sci. Albany, 28: 927933.

NRC, 1968. Nutrient Requirements of Domestic Animals, no 2. Nutrient Requirements of Swine. National Research Council, Washington, D.C.

PERRY, T.W., 1972. Effect of grain processing on their fee dinge In: Symposium on the Effect of Processing on the Nu tritional Value of Feeds, Gainesville, Flórida, p. ll-13.

PICKETT, R。A。, JoR。FOSTER e D.H。BACHE, 1963. Feed limita tion on performance and carcass charadteristics of fini shing suine。 Lafayette, Purdue University。 2p. (Research Progress Report 78)。 
PICKETT, R.A., J.R. FOSTER E R.M.PEART, 1964. Effect of fre quency of feeding and feed restrition on performance and carcass characteristies of growing-finishing pigso Lafayet te, Purdue University。 3p. (Research Progress Report 104)。

PIMENTEL GOMES, F。, 1973. Curso de Estatística Experimental . 5 ed。São Paulo, Livraria Nobel S.A. 430p.

POND, W.G. e J.H. MANER, 1974. Swine Production in Temperate and Tropical Environments. San Francisco, W。 H. Freeman and Company。 $646 \mathrm{p}$ 。

SEERLEY, R.W。, E。R。MILLER e J.A. HOEFER, 1962 a • Growth, ener $g y$ and nitrogen studies on pigs fed meal and pellets.' J. An. Sci. Albany, 21:829-833。

SEERLEY, R。W॰, E。R. MILLER e J०A。 HOEFER, 1962 b。 Rate of food passage studies with pigs equally and ad libitum fed merl and pellets. J。An。Sci。Albany, 21:834-837。

SHARMA, V.D०: L०G。YOUNG, R.G. BROWN, J. BUCHANAN-SMITH E G.H。 SMITH, 1973. Effects of frequency of feeding on energy me tabolism and body composition of young pigs. Can.J.Anim. Sci. Ottawa, 53: 157-164。

SMIDT, M.J., H.B. WEHR, D。BISSONNETTE E J.C. FRITZ, 1965。 Ob servations on factors which affect weight gain, feed con version and carcass quality in swine. Feedstuffso Minneapo lis, $\underline{37}(27): 20$ 。

SMOLINSKY, E。, M.E。 TUMBLESON, R。J。 MEADE, L.E。 HANSON e W०J。 AUNAN, 1963. Influence of restricted feeding on performan ce of growing pigs, and on carcass characteristics。 J.An。. Sci. Albany, 22:1131 (abstr)。 
STAHLY, T.S. e R.C. WAHLSTROM, 1973. Effects of dietary pro tein.level and feed.restriction on performance and car cass characteristics of suine。 J。An. Sci。Albany, 36: $1109-1113$ 。

STOTHERS, S.C., 1963。Restricted intake of pellets of mash and the performance and carcass quality of finishing pigs。 Jo An。Sci。Albany, 22:1131 (abstr)。

TRIBBLE, L。F。, A.M。LENNON e R。H。KLETT, 1973。 Lysine in meal or pelleted grain sorghum rations for swine. J.An。Sci。Al bany, 36:204 (abstr)。

WALKER, No, 1970. The effect of feeding at 3, 6 or 12 hourly intervals on the performance and carcass composition of grouing-finishing pigs。 J. Agric。Sci. Cambridge, 75: 24l244 。

WARDEN, W.Ko, 197l。pelleted feeds for livestock and poultry。 Fontiers in Nutrition Supplement。Chicago, 235:909-912。

YEN, J.T., D.H。BAKER, B.G. HARMON E A.H。 JENSEN, 1971。 COIM gluten feed in swine diets and effect of pelleting on tryp tophan availability to pigs and rats。 J. An. Sci。 Albany, 33: 987-991. 
9. APENDICE 


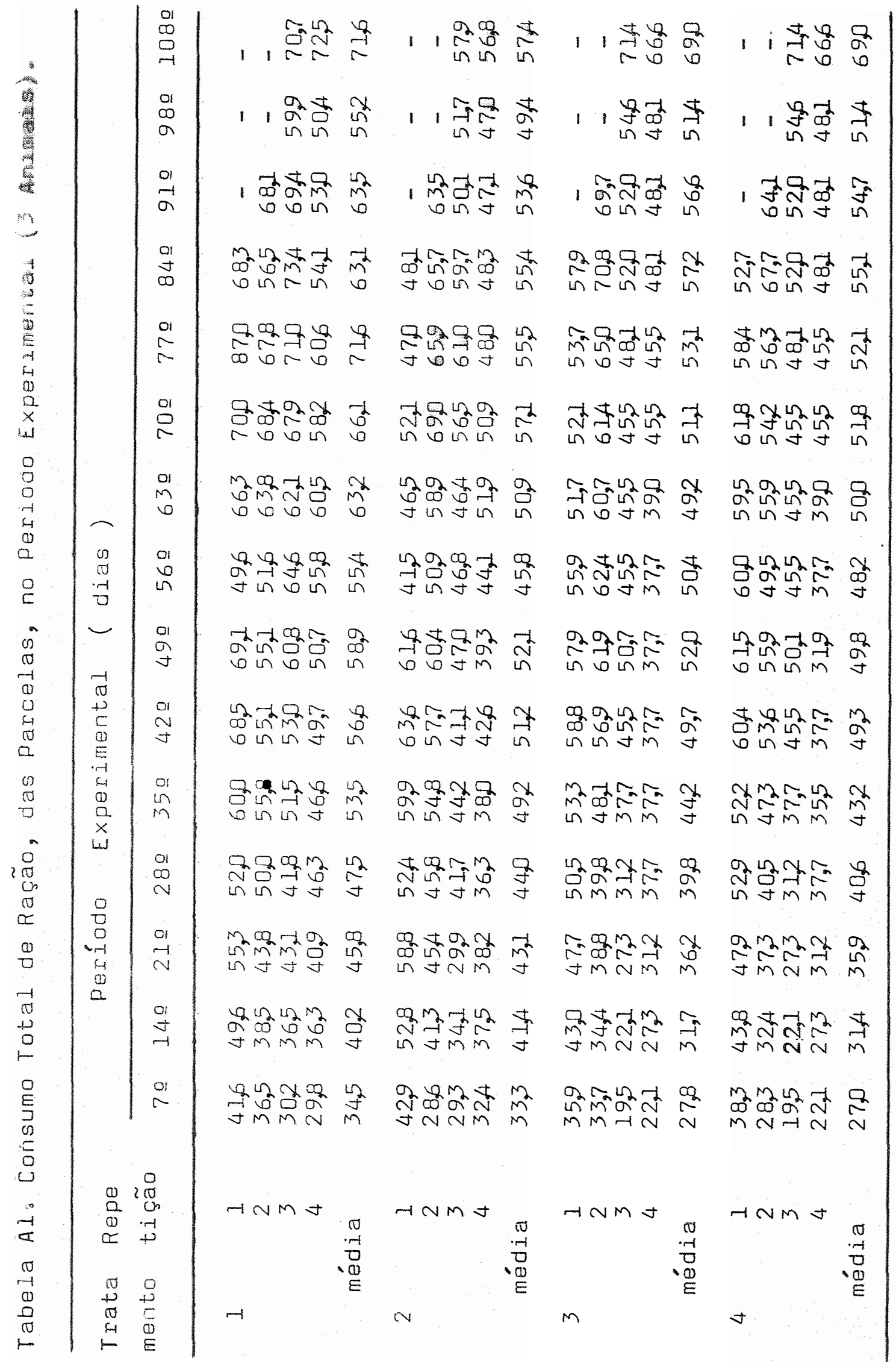


Tabela A2. Consumos Médios Diários de Ração das Repetições na Fase de Crescimento ( $k g$ ) (Média de 3 Animais).

\begin{tabular}{llllll}
\hline \multirow{2}{*}{ Tratamentos } & \multicolumn{5}{c}{ Repetições } \\
\cline { 2 - 6 } & RI & R2 & R3 & $R 4$ & média \\
\hline L-Farelada à vontade & 2,60 & 2,29 & 2,27 & 2,12 & 2,32 \\
2-Granulada à vontade & 2,62 & 2,27 & 1,87 & 1,84 & 2,15 \\
3-Farelada controlada & 2,30 & 2,13 & 1,66 & 1,60 & 1,92 \\
4-Granulada controlada & 2,34 & 2,01 & 1,66 & 1,55 & 1,89 \\
média & 2,46 & 2,18 & 1,86 & 1,78 & 2,07 \\
\hline
\end{tabular}


Tabela A3. Consumos Médios Diários de Ração das Repetições na Fase de Acabamento ( $\mathrm{kg}$ ) (Média de 3 Animais)。

\begin{tabular}{lccccc}
\hline \multirow{2}{*}{ Tratamentos } & \multicolumn{5}{c}{ Repetições } \\
\cline { 2 - 6 } & $R 1$ & $R 2$ & $R 3$ & $R 4$ & média \\
\hline 1-Farelada à vontade & 3,26 & 2,99 & 3,04 & 2,62 & 2,98 \\
2-Granulada à vontade & 2,36 & 2,97 & 2,46 & 2,24 & 2,51 \\
3-Farelada controlada & 2,61 & 3,10 & 2,37 & 2,18 & 2,56 \\
4-Granulada controlada & 2,81 & 2,76 & 2,37 & 2,18 & 2,53 \\
média & 2,76 & 2,96 & 2,56 & 2,30 & 2,64 \\
\hline
\end{tabular}


Tabela A4. Consumos Médios Diários de Ração das Repetições no Período Total (kg) (Média de 3 Animais).

\begin{tabular}{lccccc}
\hline & \multicolumn{5}{c}{ Repetições } \\
\cline { 2 - 6 } Tratamentos & $R 1$ & $R 2$ & $R 3$ & $R 4$ & média \\
\hline \multirow{2}{*}{ I-Farelada à vontade } & 2,93 & 2,60 & 2,64 & 2,36 & 2,63 \\
2-Granulada à vontade & 2,49 & 2,59 & 2,15 & 2,03 & 2,32 \\
3-Farelada controlada & 2,45 & 2,58 & 2,00 & 1,88 & 2,23 \\
4-Granulada controlada & 2,58 & 2,36 & 2,00 & 1,86 & 2,20 \\
& 2,61 & 2,53 & 2,20 & 2,03 & 2,34 \\
\hline
\end{tabular}




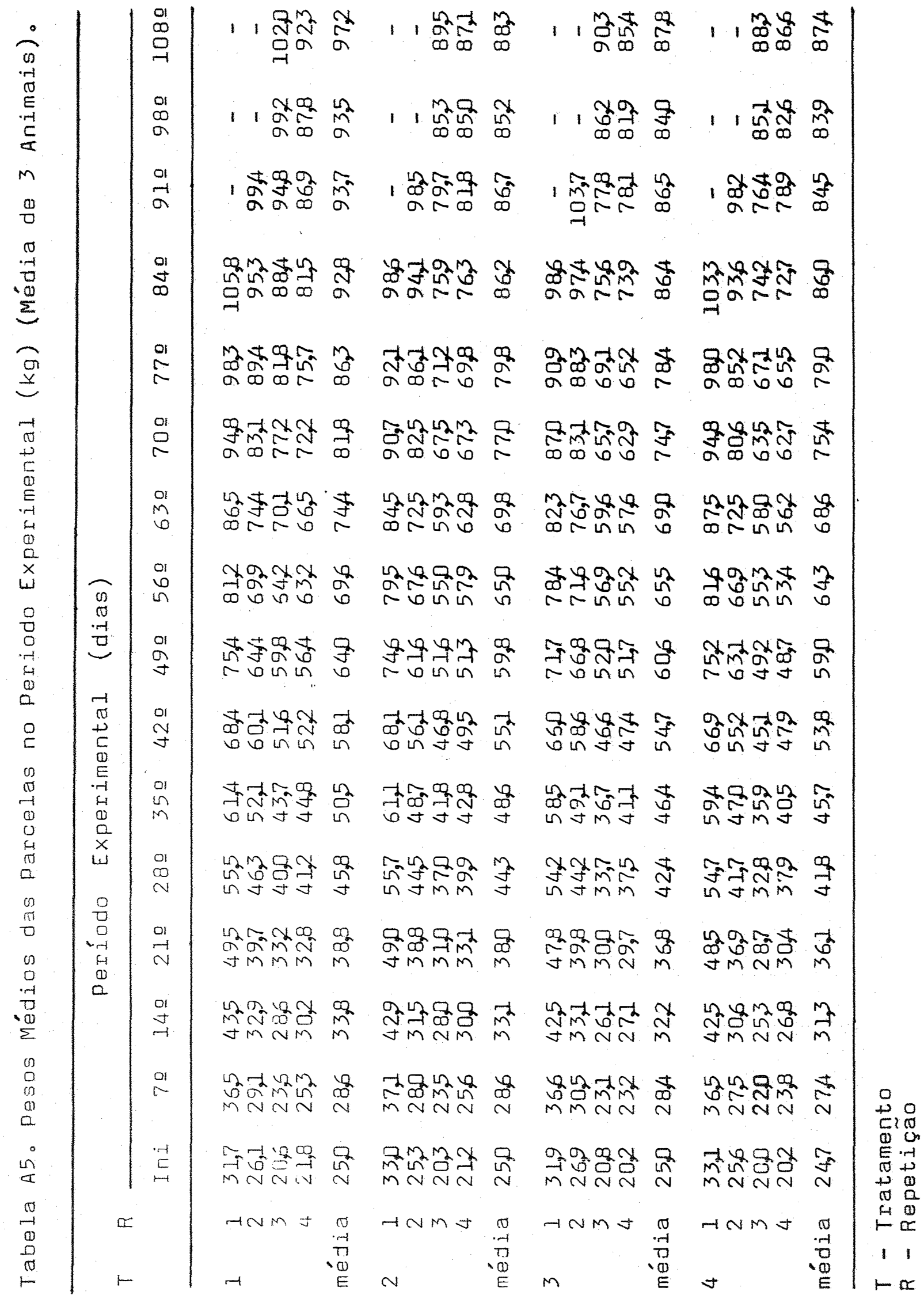


Tabola A6. Pesos Médios e Ganhos Médios de Peso dos Tratamen tos no Período Experimental (Média de 12 Animais).

\begin{tabular}{|c|c|c|c|c|c|c|c|c|}
\hline \multirow{2}{*}{$\begin{array}{l}\text { Periodo } \\
\text { Experi- } \\
\text { mental } \\
\text { (dias) }\end{array}$} & \multicolumn{2}{|c|}{$T 1$} & \multicolumn{2}{|c|}{$T 2$} & \multicolumn{2}{|c|}{$T 3$} & \multicolumn{2}{|c|}{ T4 } \\
\hline & $\begin{array}{l}\text { Peso } \\
\text { Médio } \\
(\mathrm{kg})\end{array}$ & $\begin{array}{l}\text { Ganho } \\
\text { Médio } \\
(k g)\end{array}$ & $\begin{array}{c}\text { Peso } \\
\text { Médio } \\
(k g)\end{array}$ & $\begin{array}{l}\text { Gantio } \\
\text { Médio } \\
(k g)\end{array}$ & $\begin{array}{l}\text { Peso } \\
\text { Médio } \\
(k g)\end{array}$ & $\begin{array}{l}\text { Ganho } \\
\text { Médio } \\
(k g)\end{array}$ & $\begin{array}{l}\text { Peso } \\
\text { Médio } \\
\text { (kg) }\end{array}$ & $\begin{array}{l}\text { Ganho } \\
\text { Médio } \\
\text { (kg) }\end{array}$ \\
\hline Inf́cio & 25,1 & - & 24,9 & - & 25,0 & - & 24,7 & - \\
\hline 70 & 28,6 & 3,5 & 28,5 & 3,6 & 28,3 & 3,3 & 27,5 & 2,8 \\
\hline 140 & 33,8 & 5,2 & 33,1 & 4,6 & 32,2 & 3,9 & 31,3 & 3,8 \\
\hline 210 & 38,8 & 5,0 & 38,0 & 4,9 & 36,8 & 4,6 & 36,1 & 4,8 \\
\hline 280 & 45,8 & 7,0 & 44,2 & 6,2 & 42,4 & 5,6 & 41,8 & 5,7 \\
\hline 350 & 50,5 & 4,7 & 48,6 & 4,4 & 46,4 & 4,0 & 45,7 & 3,9 \\
\hline 420 & 58,1 & 7,6 & bh, 1 & 6,5 & 54,6 & 8,2 & 53,8 & 8,1 \\
\hline 490 & 64,0 & 5,9 & 60,0 & 4,9 & 60,5 & 5,9 & 59,1 & 5,3 \\
\hline 560 & 69,6 & 5,6 & 65,0 & 5,0 & 65,5 & 5,0 & 64,3 & 5,2 \\
\hline 630 & 74.4 & 4,8 & 70,0 & 5,0 & 69,1 & 3,6 & 68,5 & 4,2 \\
\hline 700 & 81,8 & 7,4 & 77,0 & 7,0 & 74,7 & 5,6 & 75,4 & 6,9 \\
\hline 779 & 86,3 & 4,5 & 80,0 & 3,0 & 78,4 & 3,7 & 79,0 & 3,6 \\
\hline 849 & 92,8 & 6,5 & 86,2 & 6,2 & 86,4 & 8,0 & 85,9 & 6,9 \\
\hline $910^{a}$ & 93,7 & 5,3 & 86,7 & 4,6 & 86,5 & 4,2 & 84,5 & 4,3 \\
\hline $980^{b}$ & 93,5 & 2,6 & 85,1 & 4,4 & 84,0 & 6,0 & 83,8 & 6,2 \\
\hline $1080^{b}$ & 97,1 & 3,7 & 88,3 & 3,1 & 87,9 & 3,8 & 87,4 & 3,5 \\
\hline
\end{tabular}
a - Média de 9 Animais.
b - Média de 6 Animais. 
Tabela A7. Ganhos Médios Diários de Peso das Repetições na Fa se de Crescimento ( $k g$ ) (Média de 3 Animais)。

\begin{tabular}{|c|c|c|c|c|c|}
\hline \multirow{2}{*}{ Tratamentos. } & \multicolumn{3}{|c|}{ Repetições } & \multirow[b]{2}{*}{ R4 } & \multirow[b]{2}{*}{ média } \\
\hline & $R \perp$ & $R 2$ & 83 & & \\
\hline L-farelada à vontade & 0,87 & 0,78 & 0,78 & 0,74 & 0,79 \\
\hline 2-Granulada à vontade & 0,84 & 0,74 & 0,62 & 0,66 & 0,72 \\
\hline 3-Farelada controlada & 0,81 & 0,82 & 0,64 & 0,62 & 0,72 \\
\hline 4-Granulada controlada & 0,81 & 0,76 & 0,63 & 0,59 & 0,70 \\
\hline média & 0,83 & 0,78 & 0,67 & 0,65 & 0,73 \\
\hline
\end{tabular}


84.

Tabela A8. Ganhos Médios Diários de Peso das Repetições ne Fa se de Acabamento (kg) (Média de 3 Animais).

\begin{tabular}{lccccc}
\hline Tratamentos & \multicolumn{5}{c}{ Repetiçóes } \\
\cline { 2 - 6 } & $R 1$ & $R 2$ & $R 3$ & $R 4$ & média \\
\hline L-Farelada à vontade & 0,89 & 0,84 & 0,73 & 0,56 & 0,76 \\
2-Granulada à vontade & 0,72 & 0,88 & 0,66 & 0,56 & 0,70 \\
3-Farelada controlada & 0,78 & 0,88 & 0,64 & 0,58 & 0,72 \\
4-Cranulada controlada & 0,86 & 0,84 & 0,63 & 0,64 & 0,74 \\
& 0,81 & 0,86 & 0,66 & 0,58 & 0,73 \\
\hline
\end{tabular}


Tabela A9. Ganhos Médios Diários de Peso das Repetições no Pe ríodo Total (kg) (Média de 3 Animais)。

\begin{tabular}{|c|c|c|c|c|c|}
\hline \multirow{2}{*}{ Tratamentos } & \multicolumn{3}{|c|}{ Repetições } & \multirow[b]{2}{*}{84} & \multirow[b]{2}{*}{ média } \\
\hline & RI & R2 & R3 & & \\
\hline I-Farelada à vontade & 0,88 & 0,81 & 0,75 & 0,65 & 0,77 \\
\hline 2-Granulada à vontade & 0,78 & 0,80 & 0,64 & 0,61 & 0,71 \\
\hline 3-Farelada controlada & 0,79 & 0,84 & 0,64 & 0,60 & 0,72 \\
\hline 4-Granulada controlada & 0,84 & 0,80 & 0,63 & 0,62 & 0,72 \\
\hline média & 0,82 & 0,81 & 0,66 & 0,62 & 0,73 \\
\hline
\end{tabular}




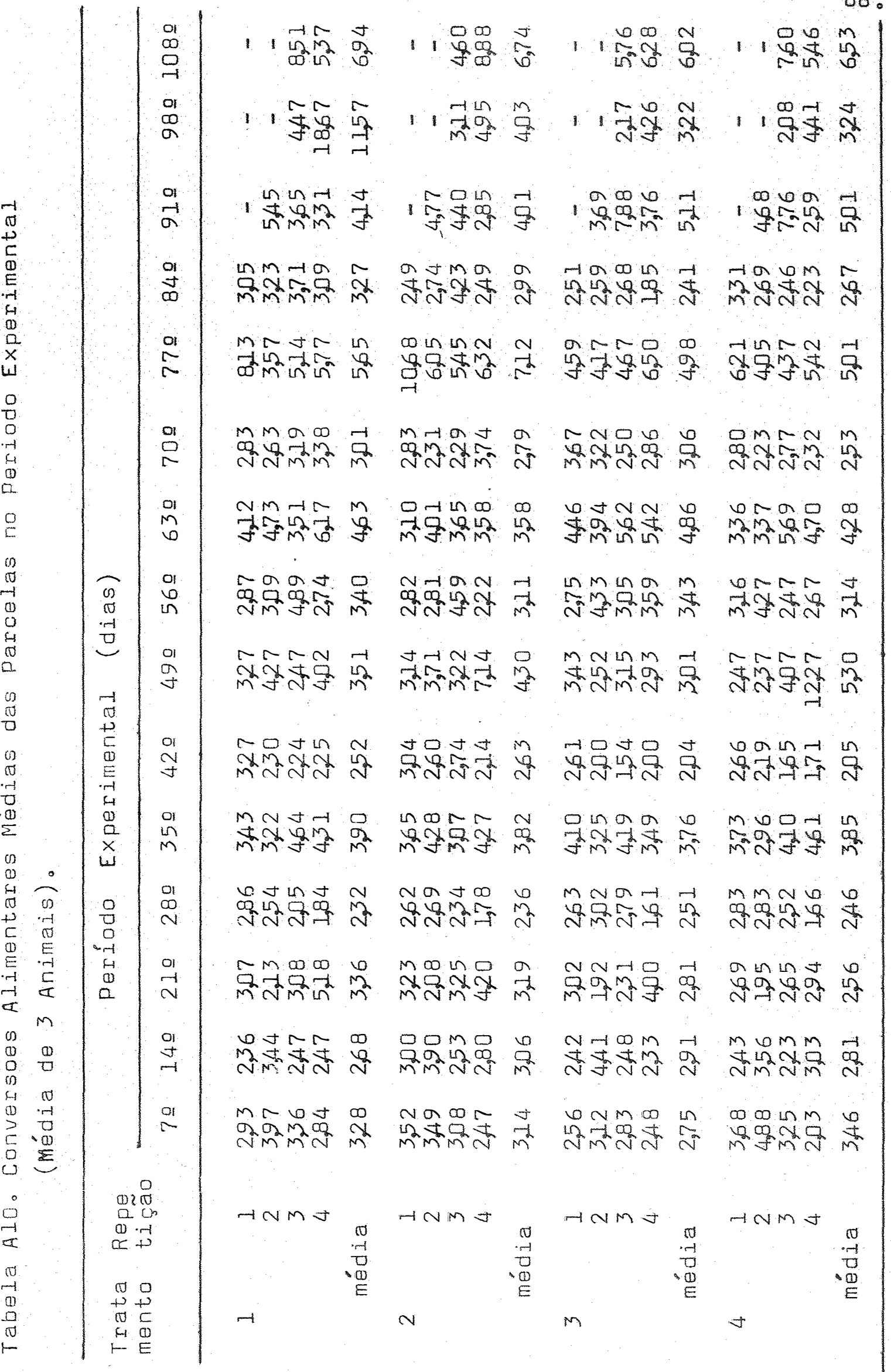


Tabela All. Conversões Alimentares Médias Diárias das Repeti ções na Fase de Crescimenta (kg ração/kg ganho).

\begin{tabular}{llllll}
\hline \multirow{2}{*}{ Tratamentos } & \multicolumn{5}{c}{ Repetiçóes } \\
\cline { 2 - 6 } & $R 1$ & $R 2$ & $R 3$ & $R 4$ & média \\
\hline I-Farelada à vontade & 2,98 & 2,91 & 2,93 & 2,87 & 2,92 \\
2-Granulada à vontade & 3,14 & 3,07 & 3,01 & 2,78 & 3,00 \\
Z-Farelada contrólada & 2,83 & 2,62 & 2,58 & 2,56 & 2,65 \\
4-Granulada controlada & 2,91 & 2,63 & 2,63 & 2,62 & 2,70 \\
média & 2,96 & 2,81 & 2,79 & 2,71 & 2,82 \\
\hline
\end{tabular}


Tabela Al2. Conversões Alimentares Médias Diárias das Repeti ções na Fase de Acabamento (kg ração/kg ganho).

\begin{tabular}{lccccc}
\hline Tratamentos & \multicolumn{5}{c}{ Repetições } \\
\cline { 2 - 6 } & $R I$ & $R 2$ & $R 3$ & $R 4$ & média \\
\hline I-Farelada à vontade & 3,65 & 3,58 & 4,19 & 4,69 & 4,03 \\
2-Granulada à vontade & 3,25 & 3,37 & 3,71 & 4,00 & 3,58 \\
3-Farelada controlada & 3,37 & 3,52 & 3,68 & 3,75 & 3,58 \\
4-Granulada controlada & 3,25 & 3,30 & 3,74 & 3,42 & 3,43 \\
média & 3,38 & 3,44 & 3,83 & 3,96 & 3,65 \\
\hline
\end{tabular}


Tabela A13. Conversões Alimentares Médias Diárias das Repeti ções no período Total ( $k g$ ração/kg ganho).

\begin{tabular}{|c|c|c|c|c|c|}
\hline \multirow{2}{*}{ Tratamentos } & \multicolumn{4}{|c|}{ Repetições } & \multirow[b]{2}{*}{ média } \\
\hline & RI & $R 2$ & R3 & R4 & \\
\hline L. - arelada à vontade & 3,32 & 3,23 & 3,51 & 3,62 & 3,42 \\
\hline 2-Granulada à vontade & 3,19 & 3,22 & 3,36 & 3,33 & 3,28 \\
\hline 3-Farelada controlada & 3,09 & 3,05 & 3,11 & 3,12 & 3,09 \\
\hline 4- Granulada controlada & 3,08 & 2,95 & 3,16 & 3,02 & 3,05 \\
\hline média & 3,17 & 3,11 & 3,28 & 3,27 & 3,21 \\
\hline
\end{tabular}




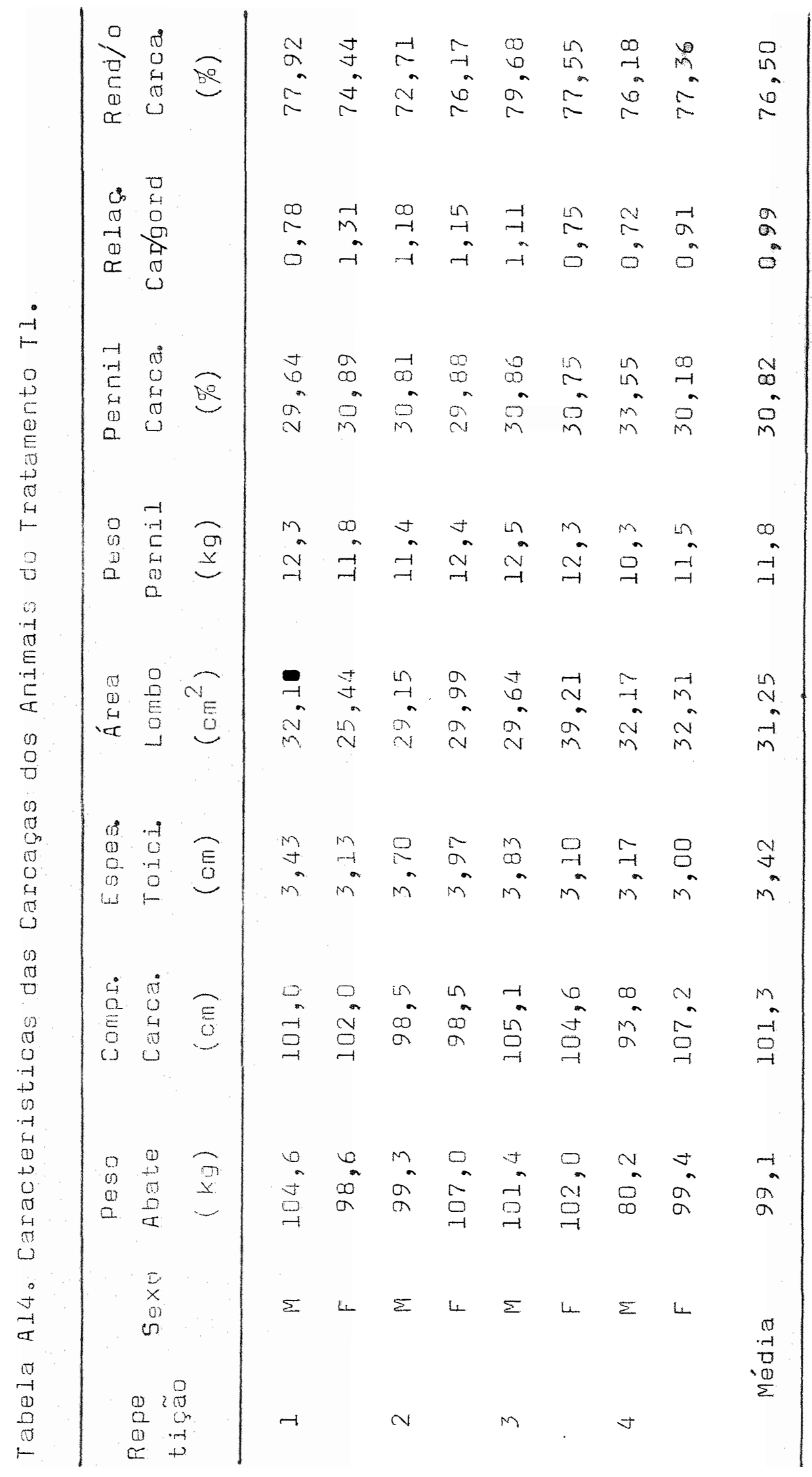




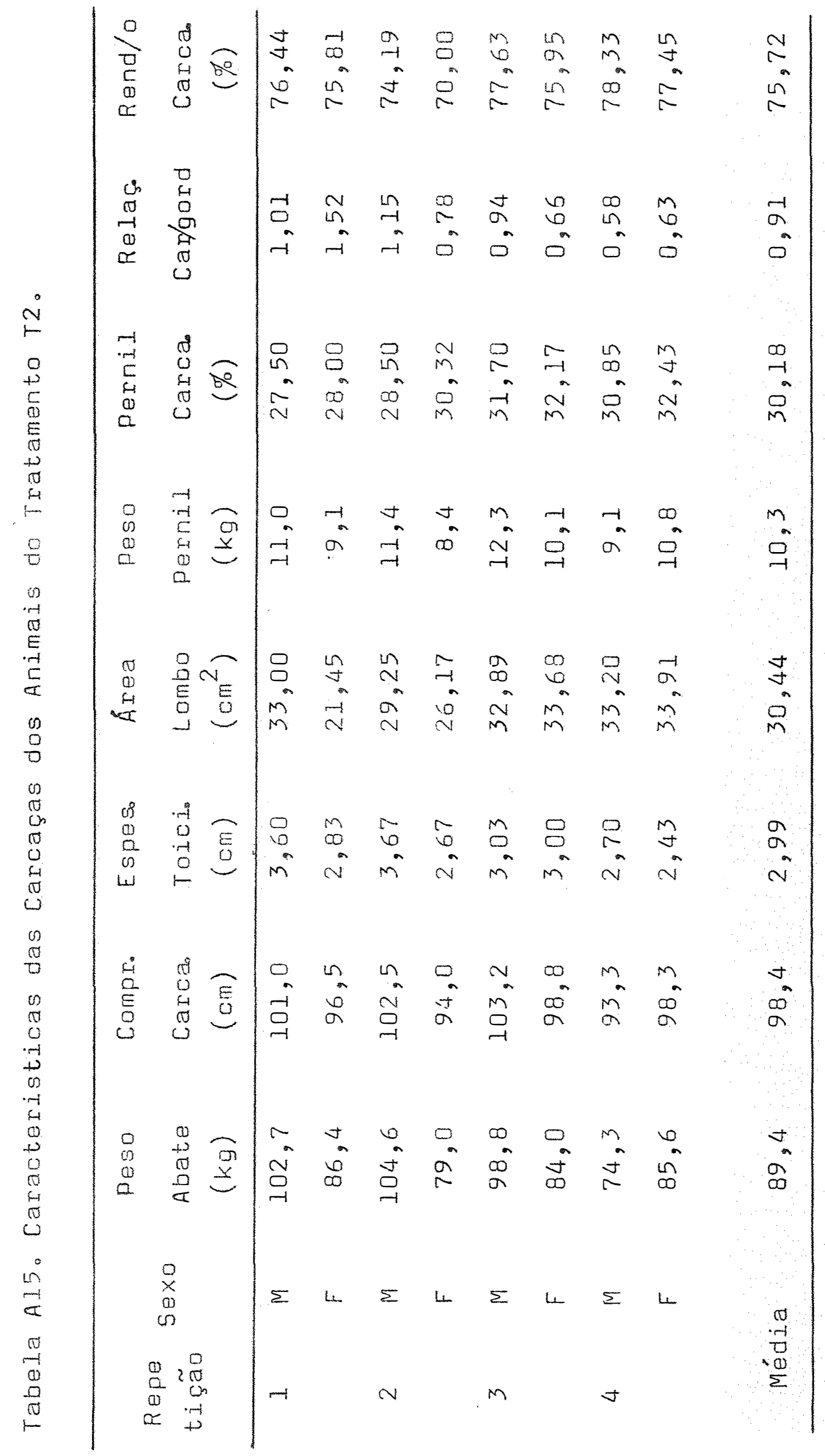




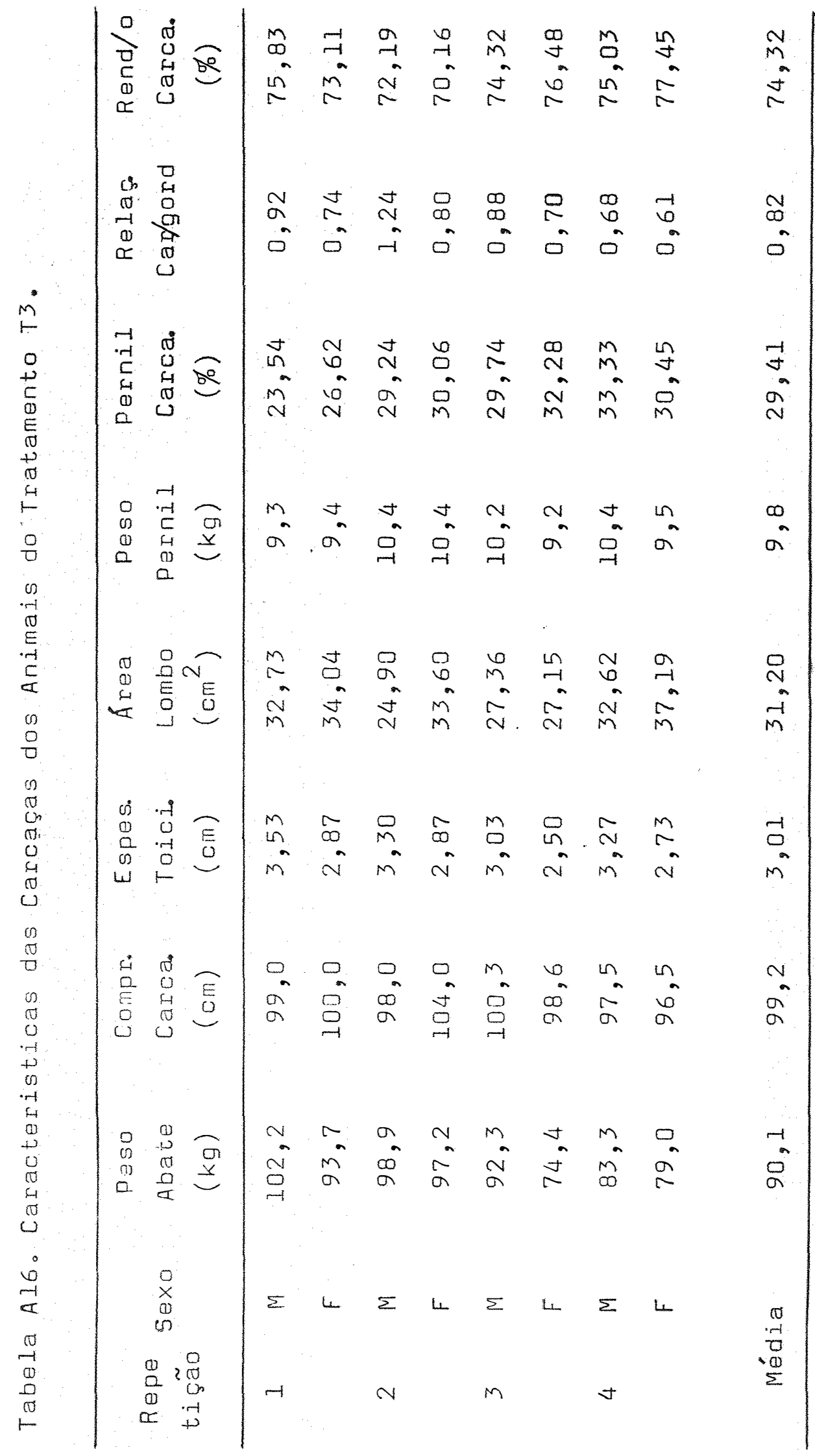




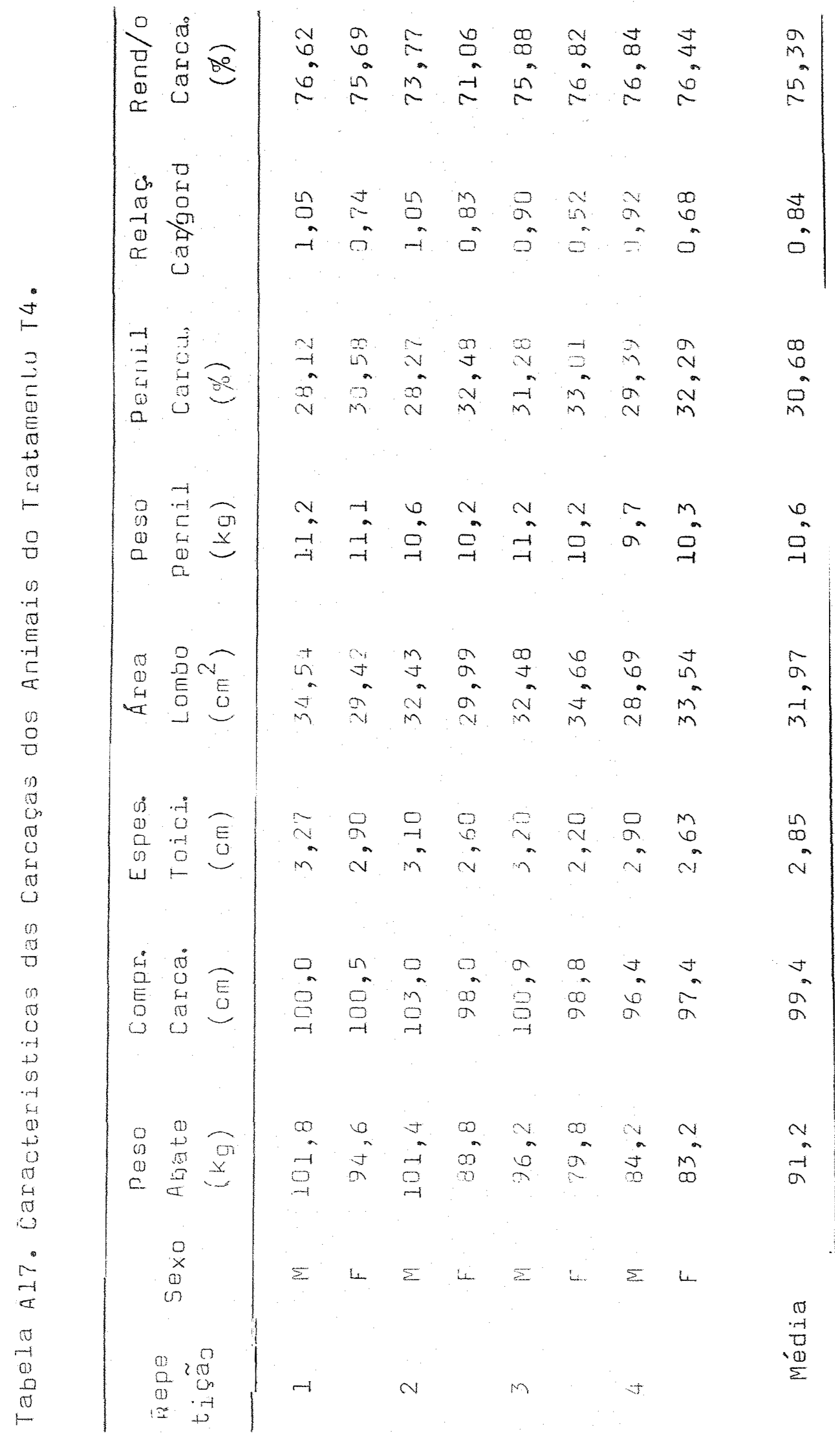

